\title{
Impact of Climate Change on Priority Plant Species Conservation in The Forests Under ONAB (the National Wood Office of Benin) Management
}

\section{S. Donalde Dolorès M. Deguenon}

Applied Ecology Laboratory, Faculty of Agronomic Sciences, University of Abomey-Calavi, Benin

\section{Rodrigue A. Idohou}

\section{T. Jean-Didier Akpona}

Laboratory of Biomathematics and Forest Estimation,

Faculty of Agronomic Sciences, University of Abomey-Calavi, Benin

\section{Fortuné Azihou}

Applied Ecology Laboratory, Faculty of Agronomic Sciences, University of Abomey-Calavi, Benin

\section{E. Achille Assogbadjo}

Applied Ecology Laboratory, Faculty of Agronomic Sciences,

University of Abomey-Calavi, Benin

Laboratory of Biomathematics and Forest Estimation,

Faculty of Agronomic Sciences, University of Abomey-Calavi, Benin

\section{Brice Sinsin}

Applied Ecology Laboratory, Faculty of Agronomic Sciences,

University of Abomey-Calavi, Benin

\section{Doi:10.19044/esj.2021.v17n10p378}

Submitted: 17 October 2020

Accepted: 03 February 2021

Published: 31 March 2021
Copyright 2021 Author(s)

Under Creative Commons BY-NC-ND

4.0 OPEN ACCESS

Cite As:

M. Deguenon S.D.D., Idohou R.A., Akpona T.J.D., Azihou F., Assogbadjo E.A. \& Sinsin B. (2021). Impact of Climate Change on Priority Plant Species Conservation in The Forests Under ONAB (the National Wood Office of Benin) Management. European Scientific Journal, ESJ, 17(10), 378. https://doi.org/10.19044/esj.2021.v17n10p378

\section{Abstract}

The sustainable conservation of forest resources in a context of climate change and population growth would be compromised in their current form of exploitation by rural communities. The objective of this study is to assess the impact of climate change on the dynamics of habitats favorable to species of 
conservation priority in the forests under ONAB management as these species are heavily used by the populations living along the shores of these forests. The study will consist of: Khaya senegalensis, Afzelia africana, Khaya grandifoliola, Pterocarpus erinaceus, Anogeissus leiocarpa, Milicia excelsa, Albizia zygia, Vitex doniana, Antidesma laciniatum and Bombax costatum. Techniques based on the principle of maximum entropy (Maxent) combined with GIS were used to project the favorable habitats of these ten species under current and future climatic conditions (Horizon 2050). Species occurrence data were collected and combined with bioclimatic data derived from the Worldclim database and the edaphic (soil) variable. Two climate models were used for future projections (CNRM-CM5, HadGEM-ES models) under the IPCC A2 scenario, and the partial ROC approach was used for the evaluation of the predictions of ecological niche models. Variables such as cec2 (cation exchange capacity, horizon 5-15cm), bio17 (precipitation of the driest quarter), bio12 (annual precipitation), bio3 (isothermality), bio6 (minimum temperature of the coldest month) and bio7 (annual thermal amplitude) were found to be the most relevant respectively for the distribution of Khaya grandifoliola, Albizia zygia, Anogeissus leiocarpa, Antidesma laciniatum, Afzelia africana and Khaya senegalensis. Under current conditions, only 7\% of the Beninese territory would be very favorable to the conservation of Khaya senegalensis and the CNRM-CM5 model predicts an increase of $27.5 \%$ and $13.2 \%$ respectively of these very favorable and moderately favorable areas by 2050 through conversion of unfavorable areas (7.4\%). On the other hand, this model predicts an opposite trend at the level of Afzelia africana where it predicts a decrease of $8.1 \%$ and $1.8 \%$ respectively of the very favorable and moderately favorable areas and an increase of $5.1 \%$ of the unfavorable areas. Ecological niche modeling has basically revealed the conversion of some currently unfavorable habitats into very favorable habitats for conservation (this is the case of Khaya grandifoliola, Khaya senegalensis and Vitex doniana) and the extension of some habitats unfavorable to conservation (Anogeissus leiocarpa, Bombax costatum, and Pterocarpus erinaceus) by 2050. This study provides scientific support for planning and is a decision support tool for the conservation of these species at the socio-economic level.

Keywords: Utilitarian species, ecological niche, classified forests, climate change, model

\section{Introduction}

Many species are becoming rare in their natural habitats because of the threats to biodiversity. Climate change is now recognized as one of the major threats to the survival of species and the integrity of ecosystems around the world. Knowledge of the specific properties of these changes, which may have 
an impact on species or their habitats, is central to adaptation strategies (Heller and Zavaleta, 2009). Since climate fluctuations influence biodiversity and determine the spatial distribution of favorable geographical areas, climate change is a crucial environmental issue that needs to be integrated into conservation planning (Fandohan et al., 2013). In addition, many plant species are used by local populations for food, medicine, and also make a substantial contribution to household income (Assogbadjo et al., 2008; Vodouhê et al., 2009). In Africa, 25-42\% of plant species could be threatened with extinction due to a loss of $81-97 \%$ of suitable habitats by 2085 (Boko et al., 2007). It is projected that $20-30 \%$ of plant and animal species will face a greater risk of extinction if global warming exceeds $1.5-2.5^{\circ} \mathrm{C}$ in Africa (Jovic et al., 2010; Parry et al., 2007).

Furthermore, much of the impressive biodiversity of sub-Saharan Africa, including Benin, remains one of the most vulnerable to the impacts of climate change (Parry et al., 2007). It is clear that fluctuations in climatic variables such as rainfall and temperature will affect biodiversity and the geographical distribution of species-friendly habitats (Parry et al., 2007). Several studies have revealed that due to the manifestations of climate change, many current crop varieties will need to be replaced in the future if cropping areas are to be maintained (Deryng et al., 2011; Duveiller et al., 2007; Jones et al., 2003). These effects are likely to be felt on species that are useful to the riparian populations of the forests under ONAB management. However, the use of ecological niche models can reveal the distribution of habitats favorable to species in the present as well as the future and is a powerful tool for understanding the current and future distribution of a species (Phillips et al., 2006). These models also allow better reasoning for the choice of areas where these species will be now and in the future in order to anticipate future changes in response to environmental disturbances (Idohou et al., 2016). However, climate change represents a threat that is fundamentally different from other threats because, in the past, ecological stress has never called into question the effectiveness of protected area networks in conserving representative samples of species (Baxter et al., 2005) or in covering habitats that are favorable to them. In short, there is considerable uncertainty (at the country and regional scales) about how these static areas will continue to conserve or provide favorable habitat for the species concerned as a result of climate change. Climate change is therefore a real challenge for the development of future policies and options in agriculture and conservation because of the uncertainties associated with it.

In Benin, 280 plant species are threatened with extinction and $90 \%$ have a high probability of extinction (Adomou, 2005). Of these, 19 are of regional conservation interest and 10 are on the IUCN Red List (Adomou, 2005). Afzelia africana and Khaya senegalensis are two of these threatened 
species, already on the Red List of the International Union for the Conservation of Nature (IUCN), although they even appear to be critically endangered in Benin (Adomou et al., 2006). In addition to these two species, which are well known for their usefulness as a source of fodder for livestock and as timber highly prized in the international timber trade, other species such as Daniellia oliveri and Anogeissus leiocarpa are proving to be very vulnerable to anthropogenic pressures and are becoming increasingly rare (Houehanou et al., 2013). Exploitation is therefore being shifted to other plant species, among which Detarium microcarpum, Prosopis africana and Burkea africana can be cited (Houehanou et al., 2013).According to Djègo-Djossou (2003), the Central Nucleus of the Lama Classified Forest, located in southern Benin, constitutes the last great remnant of the natural dense forest. Despite the monospecies nature of the plantations of the Office National du Bois du Bénin (ONAB) most of the time, they also shelter species of interest to the local population. On the one hand, the local populations have an increased need to use the forest resources of these forests under ONAB management (classified forests of Bassila, Pénéssoulou, Atchérigbé, Dogo-Kétou, Bonou, Lama, Agrimey, Djigbé). This is due to population growth, to the needs of plant organs in the pharmacopoeia, and to the accelerated and continuous degradation of the forests by the regular passage of vegetation fires and transhumant herds. On the other hand, we have the difficulties encountered in the protection policies of these classified forests and wildlife reserves, which constitute increasingly serious threats to the protection and survival of these important resources. The biodiversity of these forests is disappearing at an alarming rate. It is therefore important, in the face of this conservation problem, to ask to what extent the protected areas in Benin are effectively conserving biological diversity (Fandohan et al., 2013).

This study mainly aims at assessing the potential impact of climate change on the dynamics of habitats favorable to priority species used by the ONAB riparian populations. It thus contributes to the establishment of databases on the potential impact of climate change on certain species of interest according to the different scenarios available. Also, it could accelerate decision-making for adaptive measures. From a bioclimatic point of view, what is the extent of the areas favorable to the conservation of these primate species? With regard to climate projections, what is the potential effect of climate change on the extent of these areas and their geographical distribution by 2050 ?

\section{Materials and Methods \\ Study Environment}

This study was conducted in the Republic of Benin $\left(6^{\circ}-12.25^{\circ} \mathrm{N}\right.$; $\left.0.40^{\circ}-3^{\circ} \mathrm{E}\right)$. The study covers two biogeographical zones of Benin: the 
Sudano-Guinean zone $\left(7^{\circ} 30^{\prime} \mathrm{N}\right.$ and $\left.11^{\circ} 5^{\prime} \mathrm{N}\right)$ and the Guineo-Congolese zone $\left(6^{\circ} 25^{\prime} \mathrm{N}\right.$ and $\left.7^{\circ} 30^{\prime} \mathrm{N}\right)$ (Figure 1). The forests under ONAB management occupy from south to central Benin, two bio-geographical regions: the Guinean affinity zone and the Sudano-Guinean zone.

Figure 1: Location of plantations and forests under ONAB management by biogeographical zone in Benin

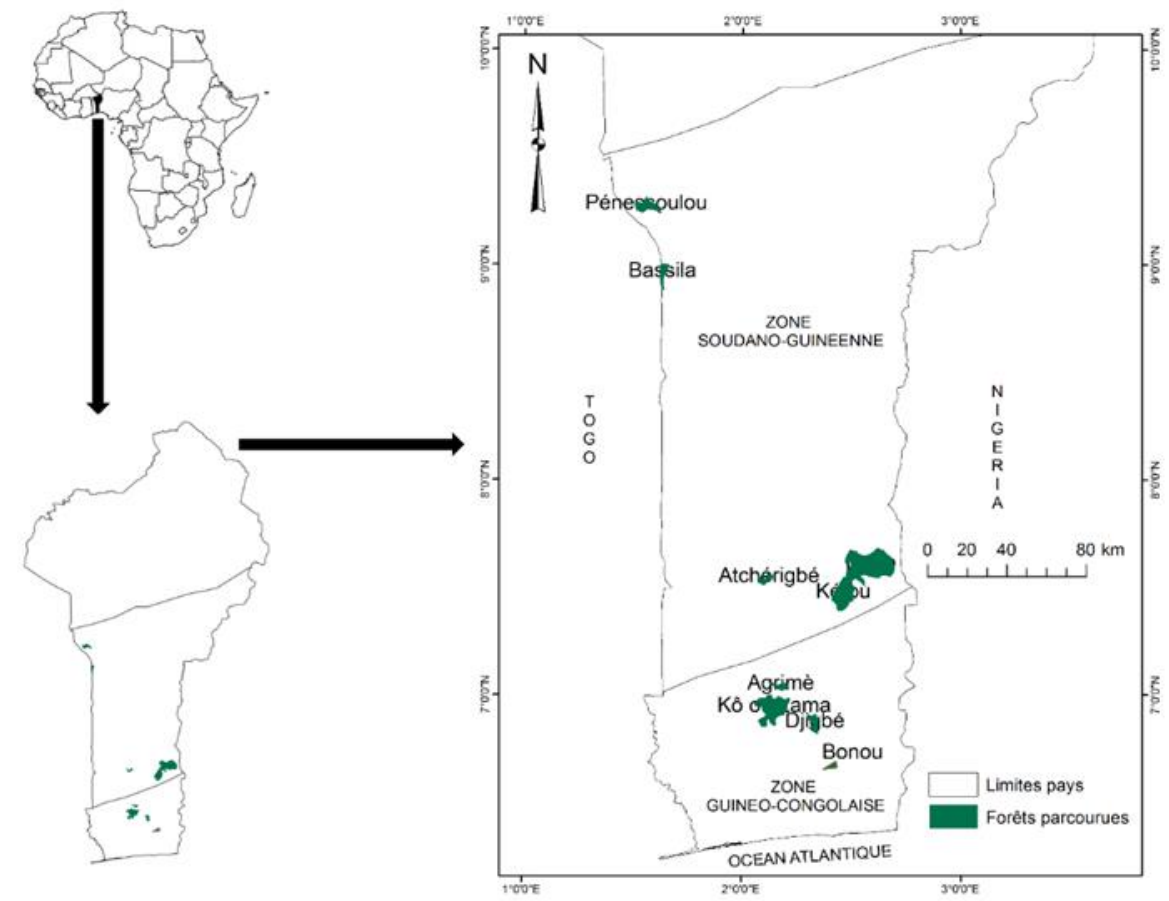

Source: Deguenon 2017

Rainfall distribution is bimodal in the Guinean zone (April to June and September to November), with an average annual rainfall of $1200 \mathrm{~mm}$. This zone has deep, low fertility ferralitic soils (700,000 ha), alluvial soils and heavy clay soils (360,000 ha) located in the valleys of the Mono, Niger, Couffo and Ouémé rivers including the Lama depression (Table 1). These soils are rich in clay, humus and inorganic elements (Sala et al., 2000).

Beyond the Guinean zone, the Sudano-Guinean zone is characterized by a unimodal rainfall distribution (May-October) with a mean annual rainfall of more than $900 \mathrm{~mm}$. In this zone, infertile mineral soils and ferruginous soils are encountered (Table 1). 
Table 1: Different climatic zones in Benin associated with climatic data and soil properties

\begin{tabular}{llllll}
\hline Zones & $\begin{array}{l}\text { Rainfall } \\
(\mathbf{m m})\end{array}$ & $\begin{array}{l}\text { RainySeasonP } \\
\text { eriods }\end{array}$ & $\begin{array}{l}\text { Temperature } \\
\left({ }^{\circ} \mathbf{c}\right)\end{array}$ & $\begin{array}{l}\text { Relative } \\
\text { Humidity (\%) }\end{array}$ & Soil Types \\
\hline $\begin{array}{l}\text { Sudano- } \\
\text { Guinean }\end{array}$ & $900-1110$ & May- October & $25-29$ & $31-98$ & $\begin{array}{l}\text { Infertile mineral } \\
\text { soils, } \\
\text { ferruginous soil }\end{array}$ \\
\hline Guinean & $\begin{array}{l}1200 \\
\text { (annual } \\
\text { average) }\end{array}$ & $\begin{array}{l}\text { April-June and } \\
\text { September- } \\
\text { November }\end{array}$ & $25-29$ & $69-97$ & $\begin{array}{l}\text { Soils ferralitic, } \\
\text { alluvial and } \\
\text { heavy clay soils }\end{array}$ \\
\hline
\end{tabular}

\section{Data Collection}

The geographical coordinates (longitude and latitude) of the presence of priority species were collected from fieldwork in protected areas and agroforestry systems in Benin. To maximize the accuracy of the modeling results, the presence coordinates of these species were completed by exploring online biodiversity databases such as the GBIF (Global Biodiversity Information Facility: www.gbif.org) and published articles on the species. Current and future climate data for the global area under consideration were downloaded from the Worldclim website (www.worldclim.org). Nineteen bioclimatic variables (Busby, 1991) were generated from the raw climate data (precipitation and temperature) prepared and put into formats compatible with the MaxEnt program. For this purpose, the QGIS software was used.

\section{Modeling and model validation}

The maximum entropy approach (Maxent, version 3.3.3 k (Phillips et al., 2006)) was used to model the ecological niche of the species. This approach is based on probability density estimation (where occurrence data are assumed to be drawn from a certain probability distribution over the study area). The Maxent models were developed using 10,000 background points. A maximum of 1000 iterations, a convergence threshold of 0.00001 , and a random $75 \%$ of the data points are set aside for the intrinsic test (Fielding and Bell, 1997; Guisan and Zimmermann, 2000). The interest of this method for this study is that it combines the observed occurrence data of a given species with the current bioclimatic characteristics at the observation points to generate: a global map of the potential habitats of the species in the area under consideration; a global map of the future distribution of these favorable habitats in relation to the climatic projections made for the area under study. Due to collinearity and dependence of climate dimensions (Zuur et al., 2010), we examined the correlations between the variables to select those that are not closely correlated $(r<0.85)$. Next, a Jackknife test was performed on the environmental variables considered to determine which ones contribute most to the modeling. A total of 28 environmental variables were identified and 
contribute to the different models according to the ecological preferences of the priority utility species, including 14 bioclimatic and 14 soil variables.

To evaluate the model, $25 \%$ of the observation points of each species were used to test the model and $75 \%$ of the points were used to calibrate the model. The area under the Receiver Operating Characteristic (ROC) curve, known as the Area Under Curve (AUC), is widely used to assess the accuracy of the prediction of distribution models. The database for each species was randomized five times in $\mathrm{R}$ software (3.4.0). A model is said to be of good quality if the AUC value is greater than 0.80 (Swets, 1988). However, some authors have begun to criticize the blind use of AUC as a measure of the level of precision in distribution models (Austin and Van Niel, 2011; Lobo et al., 2008). For this, new indices were proposed and proved to be effective in evaluating the performance of the model. Among these new approaches, we have the partial ROC approach (Wisz et al., 2008) which was used within the framework of this study. This new approach provides a firmer basis for evaluating the predictions of ecological niche models. ROC analysis is a method for assessing the specificity (absence of commission error) and sensitivity (absence of omission error) of a diagnostic test (Fielding and Bell, 1997). We calculated the partial AUCs using a program based on the trapezoidal method (Barve et al., 2011). Partial AUC values were presented as a ratio of AUC (with $\mathrm{x}$-axis modification, for traditional applications) to AUC zero expectation (which, unlike traditional approaches ROC is not equal to 0 . 5) and are variable (Wisz et al., 2008). For each species, we use the sort with the greatest partial AUC value. Significant AUC statistics rating (against zero expectations) will be achieved by resampling $50 \%$ of the test points with the replacement 1000 times from the global pool of test data. A good model should identify regions of the high probability that cover most records of presence, and areas of low probability should contain few or no points of presence (Saupe et al., 2012). The available documentation for each priority species was used to determine whether the high probability area models corresponded to areas known to contain the species.

\section{Results}

\section{Contribution of Variables and Model Validation}

The below table 2 reports on the variables that have contributed to the production of the 10 priority species models for conservation in the classified forests under $\mathrm{ONAB}$ management. Overall, species respond differently to environmental conditions. The variables most frequently used in the models produced are bio2 (mean diurnal amplitude), bio3 (isothermality), bio12 (annual precipitation), bio14 (precipitation in the driest month), bio17 (precipitation in the driest quarter), and cec5 (cation exchange capacity, horizon $60-100 \mathrm{~cm}$ ) while the variables cec1 (cation exchange capacity, 
horizon $0-5 \mathrm{~cm}$ ), clay1 (clay, horizon $0-5 \mathrm{~cm}$ ), oc1 (organic carbon, horizon 0$5 \mathrm{~cm}$ ), oc4 (organic carbon, horizon $30-60 \mathrm{~cm}$ ), bio13 (precipitation of the wettest month) and clay2 (clay, horizon $5-15 \mathrm{~cm}$ ) contribute the least to the current distribution of the 10 priority species. On the other hand, variables such as cec2 (cation exchange capacity, horizon 5-15cm), bio17 (precipitation of the driest quarter), bio12 (annual precipitation), bio3 (isothermality), bio6 (minimum temperature of the coldest), and bio7 (annual thermal amplitude) are shown to be the most relevant for the distribution of Khaya grandifoliola, Albizia zygia, Anogeissus leiocarpa, Antidesma laciniatum, Afzelia africana and Khaya senegalensis, respectively. On the other hand, variables such as bio17 (precipitation of the driest quarter), bio2 (average diurnal amplitude), bio11 (average temperature of the coldest quarter), clay2 (clay, horizon 5$15 \mathrm{~cm}$ ), bio3 (isothermality) and bio15 (seasonal precipitation) are those which contribute the least to the distribution of areas respectively of Antidesma laciniatum, Albizia zygia, Anogeissus leiocarpa, Khaya grandifoliola, Bombax costatum and Milicia excelsa. 
Table 2: Contribution of variables to the model (\%)

\begin{tabular}{|c|c|c|c|c|c|c|c|c|c|c|}
\hline Species & $K$ & $A$. & $K$ & $P$ & A. & $M$ & A. & $V$ & A. & $B$. \\
\hline Variables & senegalensis & africana & grandifoliola & erinaceus & leiocarpa & excelsa & zygia & doniana & laciniatum & costatum \\
\hline bio1 & - & - & - & - & 16.3 & - & - & 10.2 & - & - \\
\hline bio2 & - & 22.8 & 7.9 & 12.8 & - & 25.4 & 1.8 & - & - & 9.7 \\
\hline bio3 & 21.3 & - & - & - & - & 9.2 & - & - & 48.2 & 5.6 \\
\hline bio4 & - & 15.8 & - & - & - & - & 5.5 & - & - & 8.1 \\
\hline bio5 & - & - & - & - & - & - & 15 & 15.4 & - & - \\
\hline bio6 & - & 27.9 & - & 23.8 & - & - & - & - & - & - \\
\hline bio7 & 25.7 & - & - & 24.5 & - & - & - & 17 & - & - \\
\hline bio10 & - & 9.8 & - & - & - & - & - & 10.8 & - & - \\
\hline bio11 & - & - & 8.3 & 19.2 & 4 & - & - & - & - & - \\
\hline bio12 & 15.6 & - & - & 11 & 42 & - & - & - & 19.9 & - \\
\hline bio13 & - & - & - & - & - & - & 5.6 & 14.7 & - & - \\
\hline bio14 & - & - & 15.2 & - & - & 16.8 & - & - & 9.1 & 15.2 \\
\hline bio15 & - & - & - & - & - & 6.8 & - & - & 18.1 & - \\
\hline bio16 & 10.7 & 11.9 & - & 8.6 & - & - & - & - & - & - \\
\hline bio17 & - & - & - & - & - & 27.1 & 58.8 & - & 0.1 & 43.9 \\
\hline cec1 & - & - & 13.4 & - & - & - & - & - & - & - \\
\hline $\operatorname{cec} 2$ & - & - & 50.9 & - & 24.2 & - & - & - & - & - \\
\hline cec5 & - & 11.8 & - & - & 9 & 14.7 & - & - & 4.6 & - \\
\hline clay1 & - & - & - & - & - & - & - & 31.9 & - & - \\
\hline clay2 & 15 & - & 4.3 & - & - & - & - & - & - & - \\
\hline oc1 & - & - & - & - & - & - & - & - & - & 17.5 \\
\hline oc2 & 11.6 & - & - & - & - & - & 13.4 & - & - & - \\
\hline oc4 & - & - & - & - & 4.5 & - & - & - & - & - \\
\hline
\end{tabular}

bio1 (mean annual temperature), bio2 (mean diurnal amplitude), bio3 (isothermality), bio4 (seasonality), bio5 (maximum temperature of the hottest month), bio6 (minimum temperature of the coldest month), bio7 (thermal amplitude annual), bio10 (mean temperature of the warmest quarter), bio11 (mean temperature of the coldest quarter), bio12 (annual precipitation), bio13 (precipitation of the wettest month), bio14 (precipitation of the driest month) bio15 (seasonal precipitation); bio16 (precipitation from the wettest quarter), bio17 (precipitation from the driest quarter), cec1 (cation exchange capacity, horizon 0-5cm), cec2 (cation exchange capacity, horizon 5-15cm), cec5 ( cation exchange capacity, horizon 60-100cm), clay1 (clay, horizon 0-5cm), clay2 (clay, horizon 5-15cm), oc1 (organic carbon, horizon 0-5cm), oc2 (organic carbon, horizon $5-15 \mathrm{~cm}$ ), oc4 (organic carbon, horizon 30-60 cm). 


\section{Validation of Model Results}

To evaluate the performance of the models produced, the values of the mean ratio of the AUC statistic (Area Under the ROC Curve) generated by the models were used (Figure 2). Table 4 and Figure 3 report the values of the mean ratio of the AUC statistic relating to the model of each priority species for conservation in classified forests under ONAB management.

Figure 2: Maps showing the variation of AUC ratios for 1000 replicates using the Partial ROC procedure for (a) Khaya senegalensis, (b) Afzelia africana, (c) Khaya grandifoliola (d)

Pterocarpus erinaceus (e) Anogeissus leiocarpa, (f) Milicia excelsa, (g) Albizia zygia, (h) Vitexdoniana, (i) Antidesma laciniatum, (j) Bombax costatum.
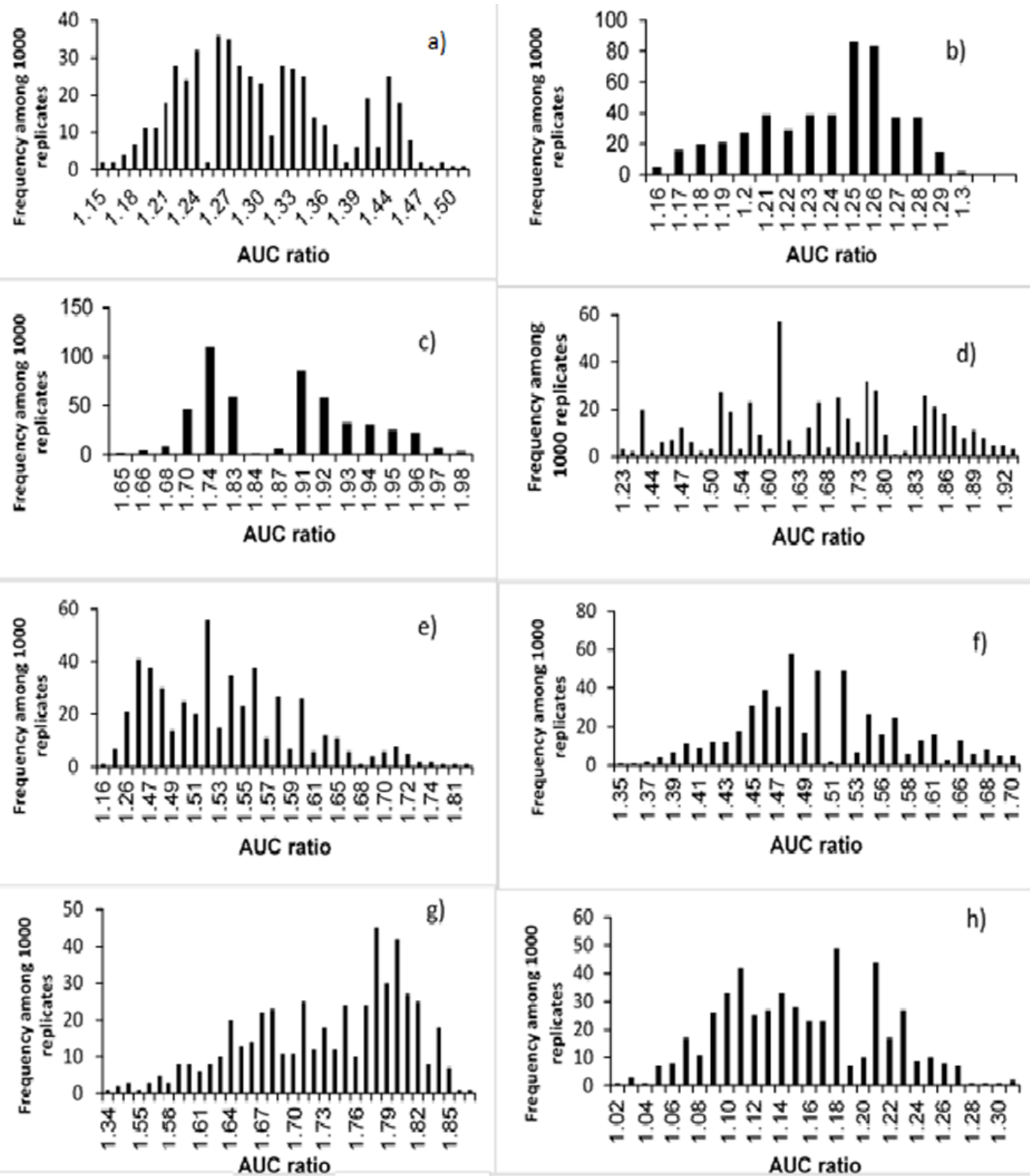
Table 3: Average AUC ratio values relating to the model of each priority species

\begin{tabular}{lll}
\hline Species & averageratioAUC & Variation \\
\hline Khaya senegalensis & 1,30 & {$[1,15 ; 1,51]$} \\
Afzelia africana & 1,24 & {$[1,16 ; 1,30]$} \\
Khaya grandifoliola & 1,85 & {$[1,65 ; 1,98]$} \\
Pterocarpus erinaceus & 1,68 & {$[1,23 ; 1,93]$} \\
Anogeissus leiocarpa & 1,52 & {$[1,16 ; 1,81]$} \\
Milicia excelsa & 1,51 & {$[1,35 ; 1,70]$} \\
Albizia zygia & 1,73 & {$[1,34 ; 1,86]$} \\
Vitex doniana & 1,16 & {$[1,02 ; 1,30]$} \\
Antidesma laciniatum & 1,52 & {$[1,19 ; 1,99]$} \\
Bombax costatum & 1,15 & {$[1,05 ; 1,47]$} \\
\hline
\end{tabular}

From the analysis of Table 3, it emerges that the value of the mean ratio of the AUC statistic for each priority species is greater than 1 . Therefore, the model is very efficient for each of these species. Thus, the current distribution areas predicted by the model for each species constitute areas of high probability where the species would be present or absent depending on the related ecological conditions.

\section{Impact of Climate Change on the Extent of Habitats Favorable for the Conservation of the 10 Priority Species in Forests Classified Under ONAB Management}

- Khaya senegalensis

According to the modeling results, around 7\% of Benin's national territory (not including the islands on the Niger River) is currently very favorable for the conservation of Khaya senegalensis (Figure 3a1, Table 4). These habitats, which are very favorable to the conservation of the species, are essentially between $9.5^{\circ}$ and $8.5^{\circ}$ then $7.5^{\circ}$ and $6.5^{\circ}$ North latitude, which corresponds respectively to the dry subhumid and humid subhumid zone. Habitats unfavorable to the species are found throughout the country, mainly between $12^{\circ}$ and $10^{\circ}$ (arid zone, dry subhumid) and below $7.3^{\circ}$ (humid subhumid zone).

According to the bioclimatic projections of the CNRM-CM5 model, Khaya senegalensis will experience an expansion of nearly $27 \%$ of habitats which are currently very favorable for conservation by 2050 (Table 4). This model also predicts shrinkage of nearly $7 \%$ of habitats that are unfavorable to the species, mainly by conversion of currently moderately favorable habitats.

The HadGEM-ES model the species will experience an expansion of nearly $8 \%$ of habitats that are currently very favourable for conservation by 2050 (Table 4). However, compared to the previous one, this model predicts the conversion of unfavorable habitats into moderately favorable habitats for the conservation of Khaya senegalensis, especially between $9^{\circ}$ and $7.5^{\circ}$ North latitude (Table 4, figure 3c1). 


\section{- Afzelia Africana}

The modeling results reveal that around $16 \%$ of Benin's territory (not including the islands on the Niger River) are currently very favorable for the conservation of Afzelia africana (Figure 3a2, Table 4). These habitats, which are very favorable for the conservation of the species, are essentially between $11^{\circ}$ and $7^{\circ}$ North latitude, which corresponds to the dry subhumid and humid subhumid zone. Habitats unfavorable to the species are more below $8^{\circ}$ (humid subhumid zone) and above $11^{\circ}$ (arid zone).

According to the bioclimatic projections of the CNRM-CM5 model, a reduction of nearly $8 \%$ of highly favorable conservation areas is forecast for Afzelia africana by 2050 (Table 4). We will also observe an extension of the less favorable areas mainly by conversion of the currently moderately favorable areas (Figure 3b2).

The HadGEM-ES model gives opposite trends. Indeed, compared to the previous one, this model predicts an extension of areas very favorable to the conservation of the species, particularly between $9.2^{\circ}$ and $8.5^{\circ}$ North latitude by conversion of less favorable areas but also of relatively favorable area (Figure 3c2).

\section{- Khaya grandifoliola}

Modeling reveals that a small portion (about 2.2\%) of Benin's territory (not including the islands on the Niger River) is currently very favorable for the conservation of Khaya grandifoliola (Figure 3a3, Table 4). These habitats, which are very favorable for the conservation of the species, are essentially between $9.3^{\circ}$ and $9^{\circ}$ then below $7.2^{\circ}$ North latitude, which corresponds respectively to the dry subhumid and humid subhumid zone. Habitats unfavorable to the species are found throughout the country; mainly between $12.2^{\circ}$ and $6.5^{\circ}$ (arid zone, dry subhumid and humid subhumid zone).

According to the bioclimatic projections of the CNRM-CM5 model, we will observe a reduction in very favorable and moderately favorable areas, respectively, of nearly (18\%) and 24\% for Khaya grandifoliola by 2050 (Table $4)$.

The HadGEM-ES model predicts an opposite trend. We will observe an extension of very favorable areas (Table 4). It also predicts an extension of moderately favorable areas (Figure $3 \mathrm{c} 3$ ) essentially between $9.2^{\circ}$ and $8^{\circ}$ North latitude by conversion of areas not very favorable to the species.

\section{- Pterocarpus erinaceus}

The results of the modeling reveal that around 3\% of Benin's territory (not including the islands on the Niger River) is currently very favorable to the conservation of Pterocarpus erinaceus (Figure 3a4, Table 4). These habitats, which are very favorable to the conservation of the species, are essentially between $9.2^{\circ}$ and $8.8^{\circ}$ North latitude, which corresponds to the dry 
subhumid zone. Habitats unfavorable to the species are the most common across the country in all three climates.

According to the bioclimatic projections of the CNRM-CM5 model, a reduction in the very favorable and moderately favorable areas of Pterocarpus erinaceus will be observed (Figure 3b4, Table 4).

The HadGEM-ES model gives opposite trends. Indeed, compared to the previous one, this model predicts rather the extension of very favorable and moderately favorable areas (Figure 3c4) by a conversion of unfavorable habitats, particularly between $12^{\circ}$ and $7^{\circ}$ North latitude.

\section{- Anogeissus leiocarpa}

According to the results of the modeling, around $5 \%$ of the national territory (not including the islands on the Niger River) are currently very favorable for the conservation of Anogeissus leiocarpa (Figure 3a5, Table 4). These habitats, which are very favorable for the conservation of the species, are essentially between $12.2^{\circ}$ and $10.8^{\circ}$ then below $8^{\circ}$ North latitude, which corresponds respectively to the arid zone and the humid subhumid zone. The most extensive habitats unfavorable to the species are throughout the country, essentially between $10.5^{\circ}$ and $7.5^{\circ}$ North latitude.

According to the bioclimatic projections of the CNRM-CM5 model, for Anogeissus leiocarpa a reduction of $42.33 \%$ of the very favorable areas will be observed (Table 4). Also, we will observe an extension of moderately favorable areas for the species, especially below $7^{\circ}$ North latitude (humid subhumid zone; Figure 3b5).

The HadGEM-ES model for Anogeissus leiocarpa a reduction of $46.66 \%$ of the very favorable areas will be observed (Table 4). It also foresees the conversion of unfavorable habitats into moderately favorable habitats for the conservation of this species, particularly between $8.8^{\circ}$ and $7^{\circ}$ north latitude (Figure 3c5).

\section{- Milicia excels}

According to the modeling, around $8 \%$ of Benin's territory is currently very favorable for the conservation of Milicia excelsa (Figure 3a6, Table 4). These habitats, which are very favorable for the conservation of the species, are mainly included below $7.3^{\circ}$ North latitude, which corresponds to the humid subhumid zone. Habitats unfavorable to the species are found further north of the country, mainly between $12^{\circ}$ and $10^{\circ}$ (arid zone, dry subhumid).

According to the bioclimatic projections of the CNRM-CM5 model, there will not be a great variation in Milicia excelsa. Nevertheless, $0.1 \%$ of very favorable areas will convert into moderately favorable areas by 2050 (Table 4).

The HadGEM-ES model gives opposite trends. In fact, compared to the previous one, this model predicts a higher extension of very favorable and 
unfavorable areas by conversion of moderately favorable areas (table 4 , figure $3 \mathrm{c} 6)$.

\section{- Albizia zygia}

About $5 \%$ of the Beninese territory (not including the islands on the Niger River) is currently very favorable to the conservation of Albizia zygia (Figure 3a7, Table 4). These habitats, which are very favorable for the conservation of the species, are essentially below $8^{\circ}$ North latitude, which corresponds to the humid subhumid zone. Habitats not very favorable to the species are the most extensive, mainly between $12^{\circ}$ and $7.8^{\circ}$ (arid, dry subhumid zone).

According to the bioclimatic projections of the CNRM-CM5 model, we will observe a conversion of nearly $40 \%$ of very favorable areas into moderately favorable areas by 2050 (Table 4, Figure 3b7).

The HadGEM-ES model gives similar trends. It predicts a conversion of $13.06 \%$ of very favorable areas to moderately favorable areas by 2050 (Table 4, Figure 3b7).

- Vitex doniana

According to the results of the modeling, around $13 \%$ of Benin's national territory (not including the islands on the Niger river) are currently very favorable to the conservation of Vitex doniana (Figure 3a8, Table 4). These habitats, which are very favorable for the conservation of the species, are mainly between $11.8^{\circ}$ and $10^{\circ}$ then below $8^{\circ}$ North latitude, which corresponds respectively to the dry subhumid and humid subhumid zone. Habitats unfavorable to the species are mainly located in the arid and dry subhumid zone.

According to the bioclimatic projections of the CNRM-CM5 model, about $4 \%$ of areas very favorable to the species will be converted into less favorable areas by 2050 (Table 4, Figure 3b8).

The HadGEM-ES model gives opposite trends. In fact, compared to the previous one, this model predicts a large number (almost ten times more) the conversion of unfavorable habitats into very favorable and moderately favorable habitats for the conservation of Vitex doniana, in particular between $11.8^{\circ}$ and $10^{\circ}$ then in below ${ }^{\circ}$ North latitude (Table 4, figure $3 \mathrm{c} 8$ ).

\section{- Atidesma laciniatum}

According to the results, around $28 \%$ of Benin's territory (not including the islands on the Niger River) is currently very favorable for the conservation of Antidesma laciniatum (Figure 3a9, Table 4). These habitats, which are very favorable for the conservation of the species, are essentially between $10^{\circ}$ and $7.5^{\circ}$ North latitude, which corresponds to the dry subhumid and humid subhumid zone. Habitats unfavorable to the species are found further north of the country; mainly above $11^{\circ}$ North latitude (arid zone). 
According to the bioclimatic projections of the CNRM-CM5 model, we will observe a reduction of nearly (19.5\%) of currently very favorable areas by 2050 (Table 4). These habitats will essentially be converted into habitats that are not very favorable to its conservation (Figure 3b9).

The HadGEM-ES model, compared to the previous one, predicts more the conversion of unfavorable habitats (around 5.22\%) and moderately favorable (around 5.6\%) to the conservation of Antidesma laciniatum into very favorable areas, particularly between $10^{\circ}$ and $6,8^{\circ}$ North latitude (Table 4, figure $3 \mathrm{c} 9$ ).

\section{- Bombax costatum}

About $27 \%$ of the national territory (not including the islands on the Niger River) are currently very favorable to the conservation of Bombax costatum (Figure 3a10, table 4). These habitats, which are very favorable to the conservation of the species, are essentially between $12^{\circ}$ and $8^{\circ}$ North latitude, which corresponds to the dry and arid subhumid zone. Habitats unfavorable to the species are mainly below $8^{\circ}$ (humid subhumid zone).

According to the bioclimatic projections of the CNRM-CM5 model, we will note an extension of the less favorable areas of Bombax costatum, in particular by converting the moderately favorable areas by 2050 (Table 4).

The HadGEM-ES model, compared to the previous one, predicts more the conversion of very favorable habitats (about 40\%) into habitats not very favorable for the conservation of Bombax costatum, in particular between $12^{\circ}$ and $8^{\circ}$ North latitude (Table 4, figure $3 \mathrm{c} 10$ ). 
Figure 3: Habitats favorable to the 10 priority species for conservation (current (a) and future distribution (CNRM-CM5: b; HadGEM-ES: c): 2050 as predicted by climate models)
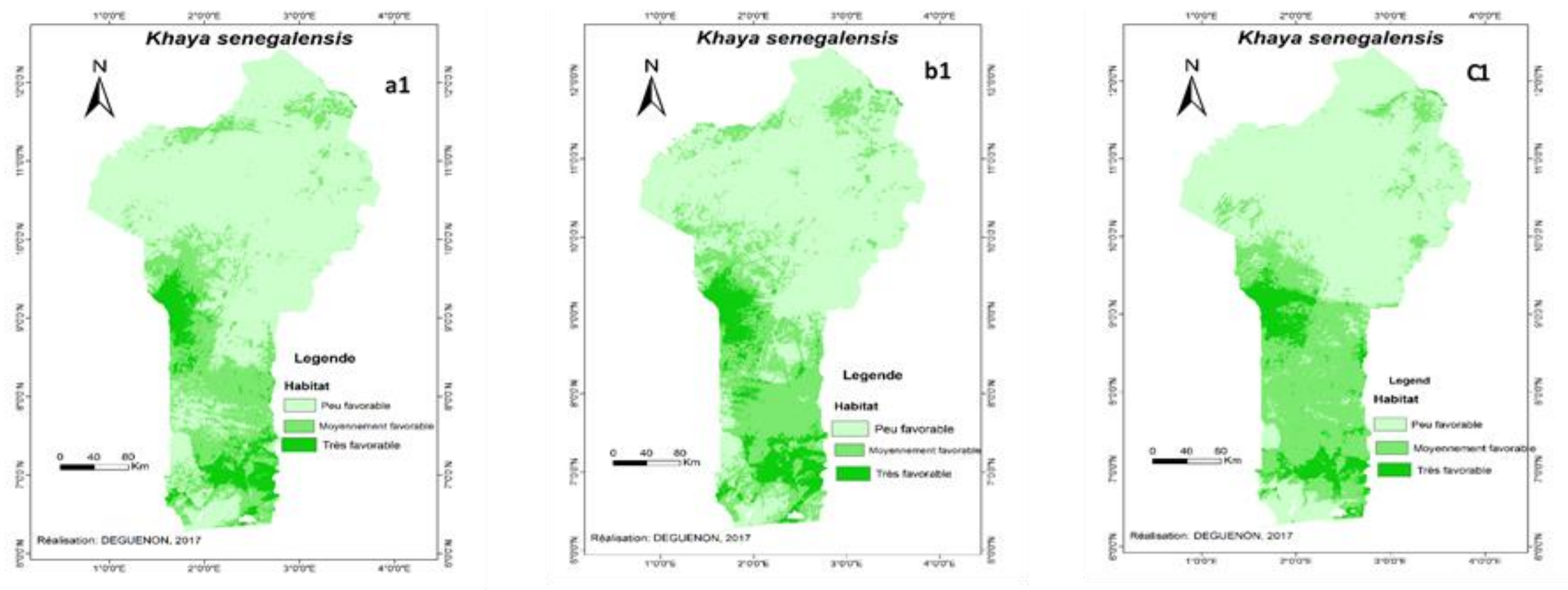
European Scientific Journal, ESJ

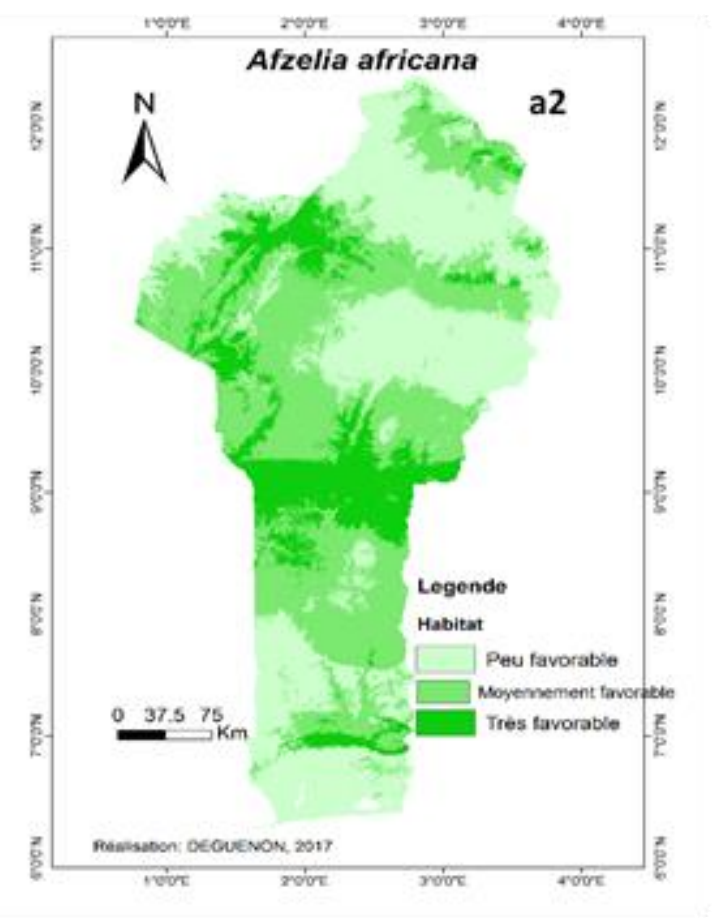

ISSN: 1857-7881 (Print) e - ISSN 1857-7431

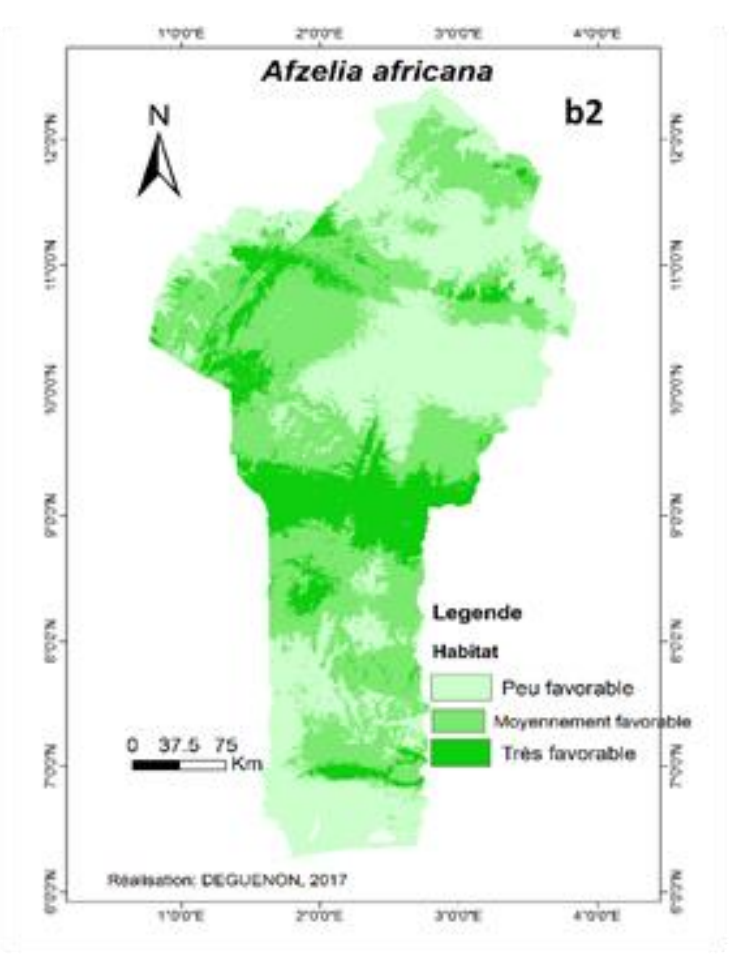

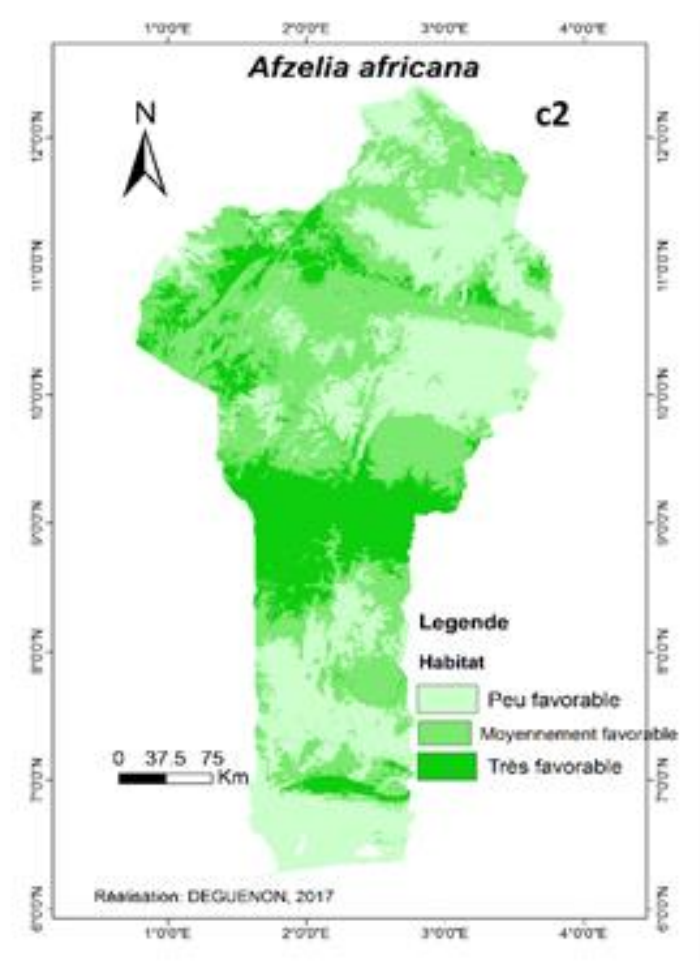


European Scientific Journal, ESJ

March 2021 edition Vol.17, No.10

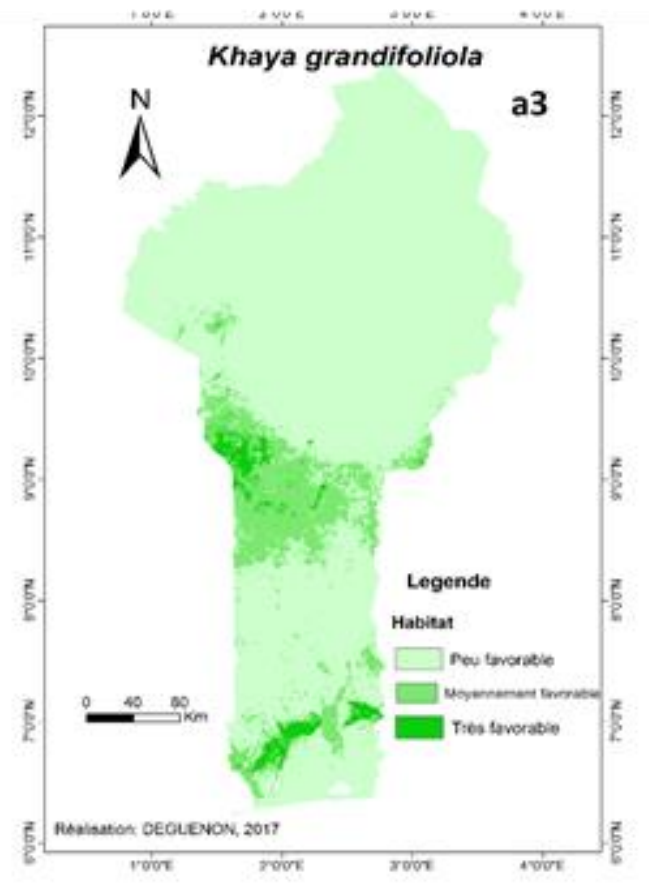

ISSN: 1857-7881 (Print) e - ISSN 1857-7431

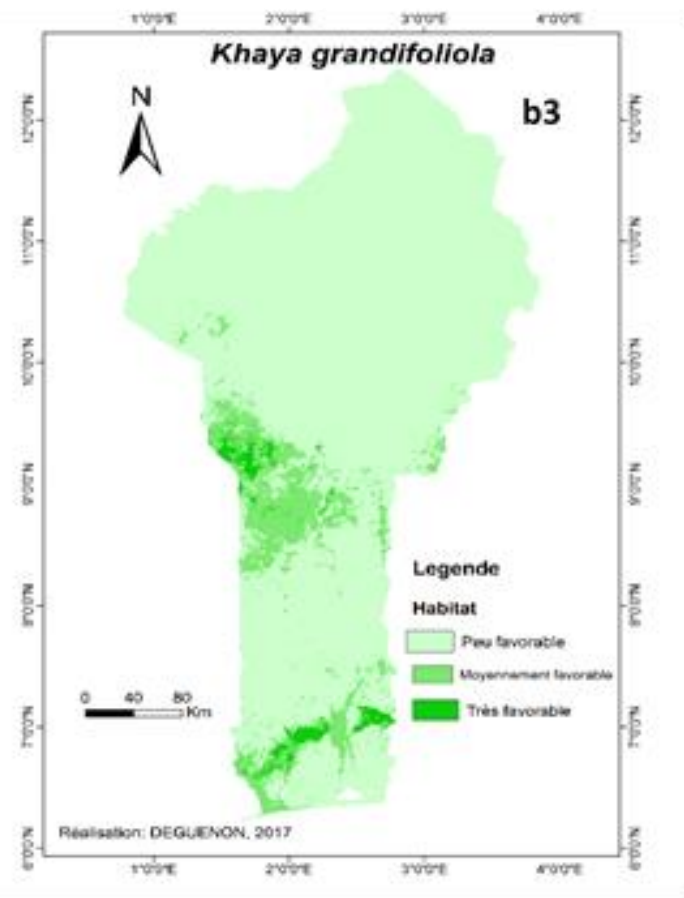

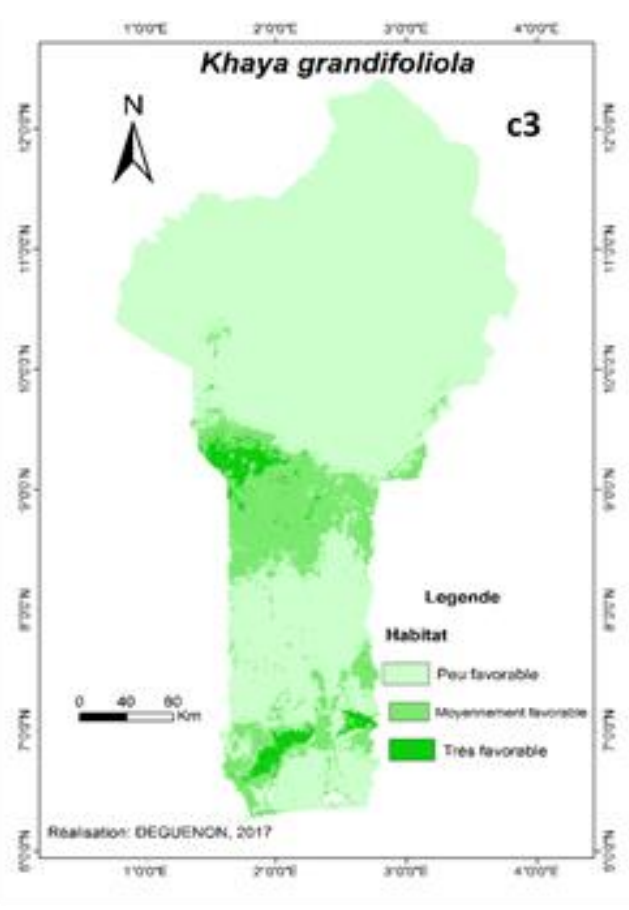


European Scientific Journal, ESJ

March 2021 edition Vol.17, No.10

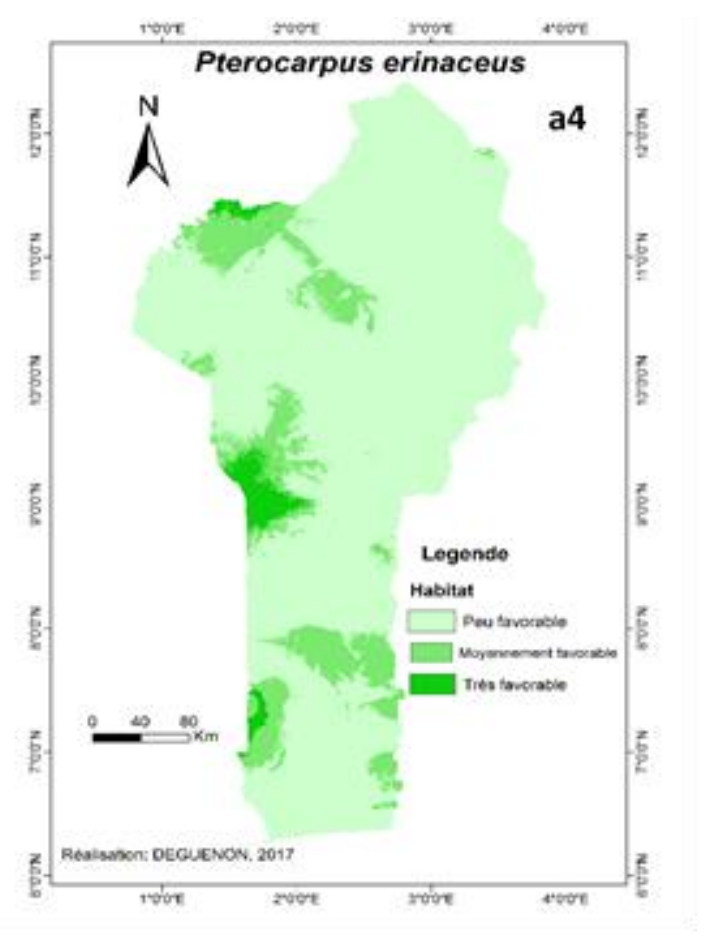

ISSN: 1857-7881 (Print) e - ISSN 1857-7431

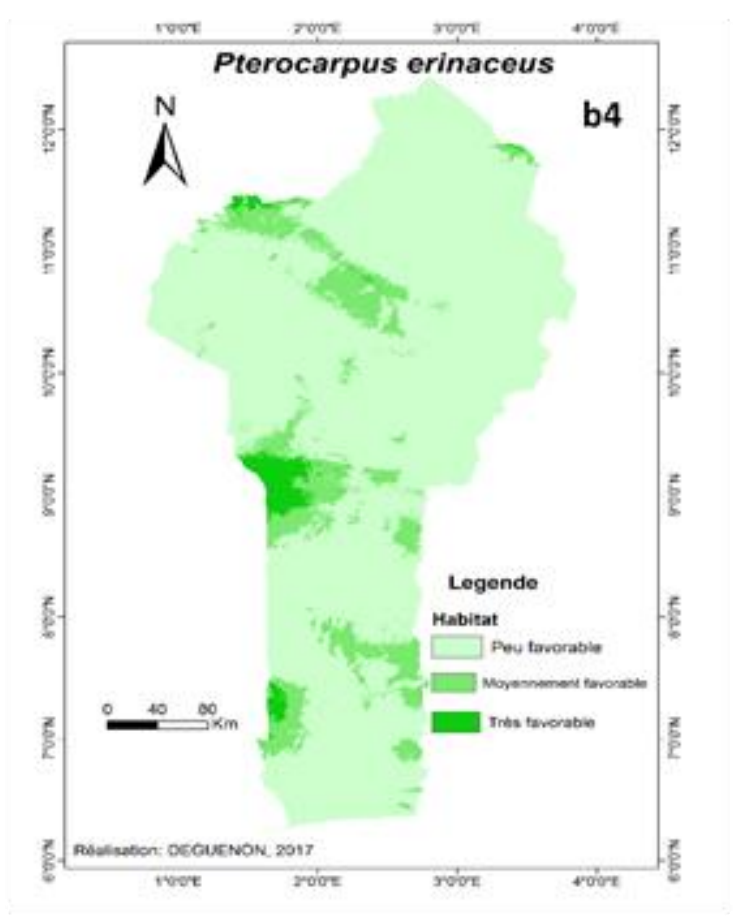

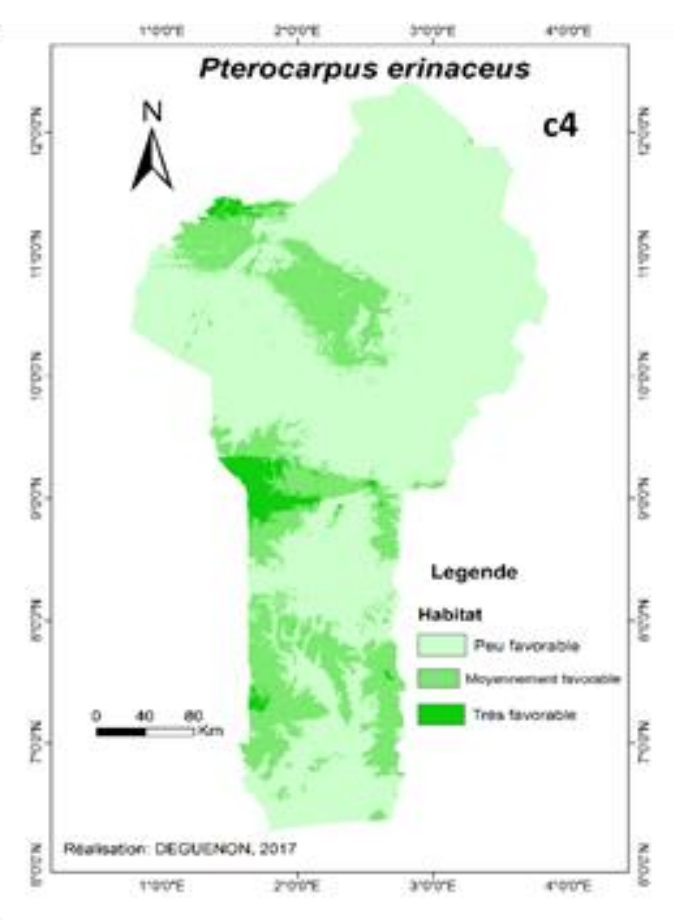


European Scientific Journal, ESJ

March 2021 edition Vol.17, No.10

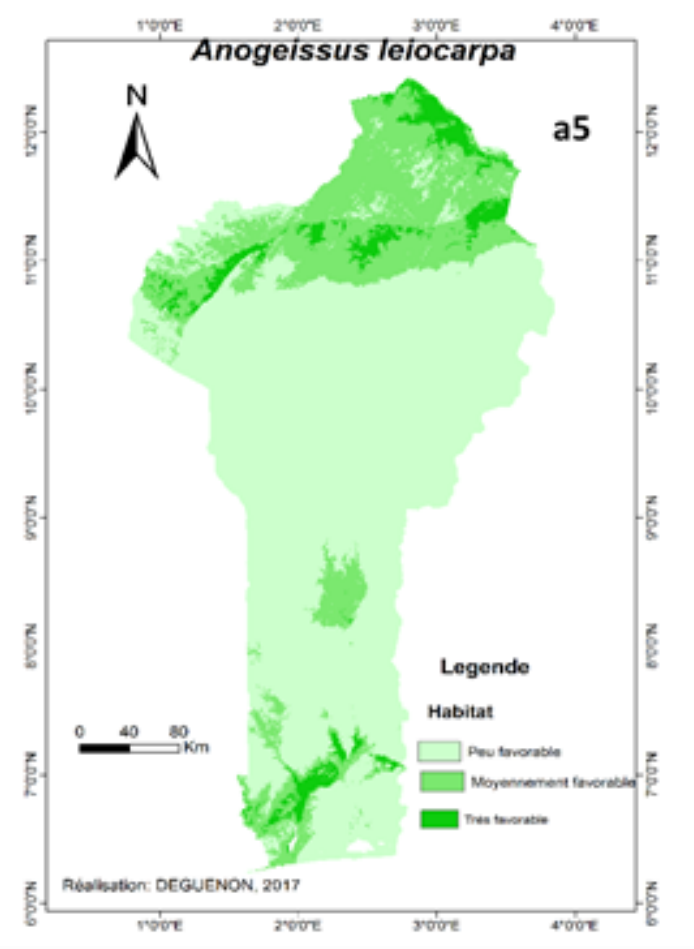

ISSN: 1857-7881 (Print) e - ISSN 1857-7431

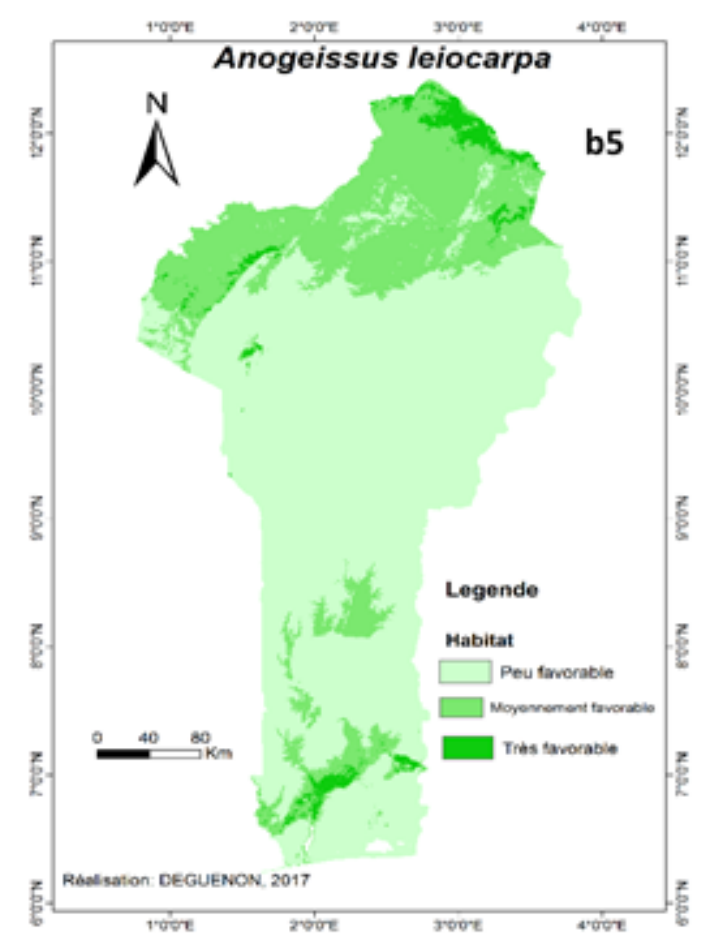

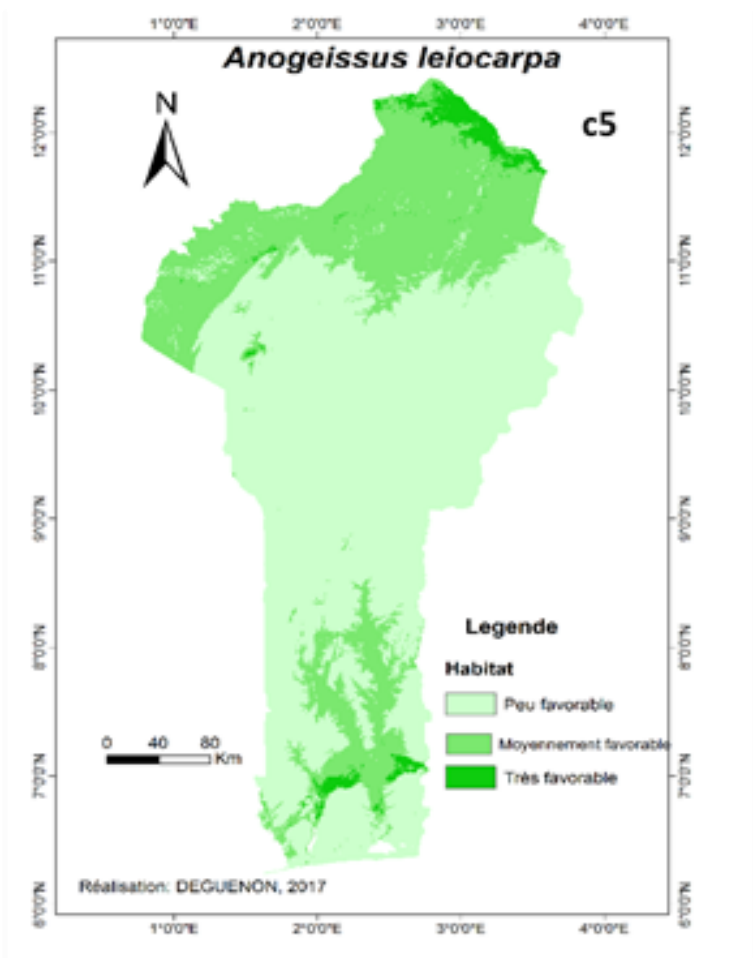


European Scientific Journal, ESJ

March 2021 edition Vol.17, No.10

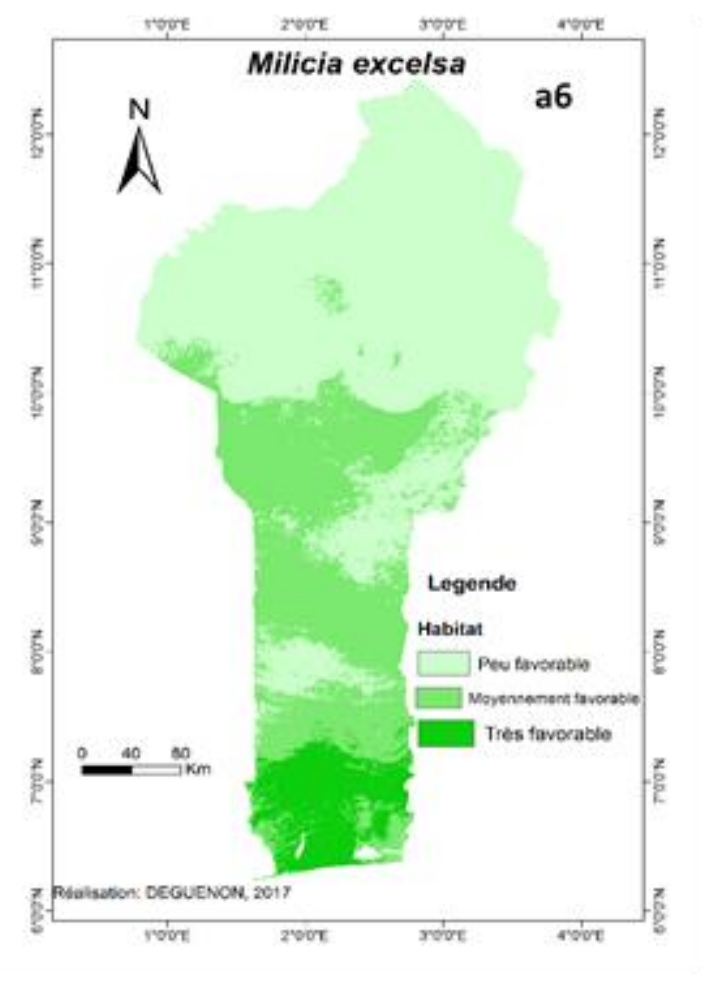

ISSN: 1857-7881 (Print) e - ISSN 1857-7431

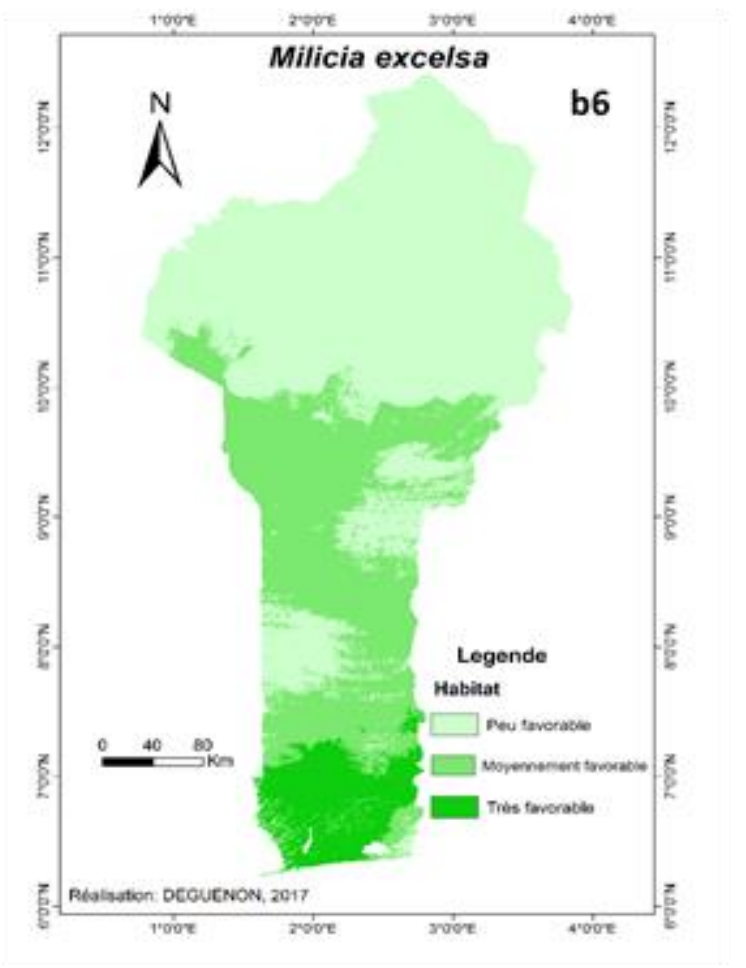

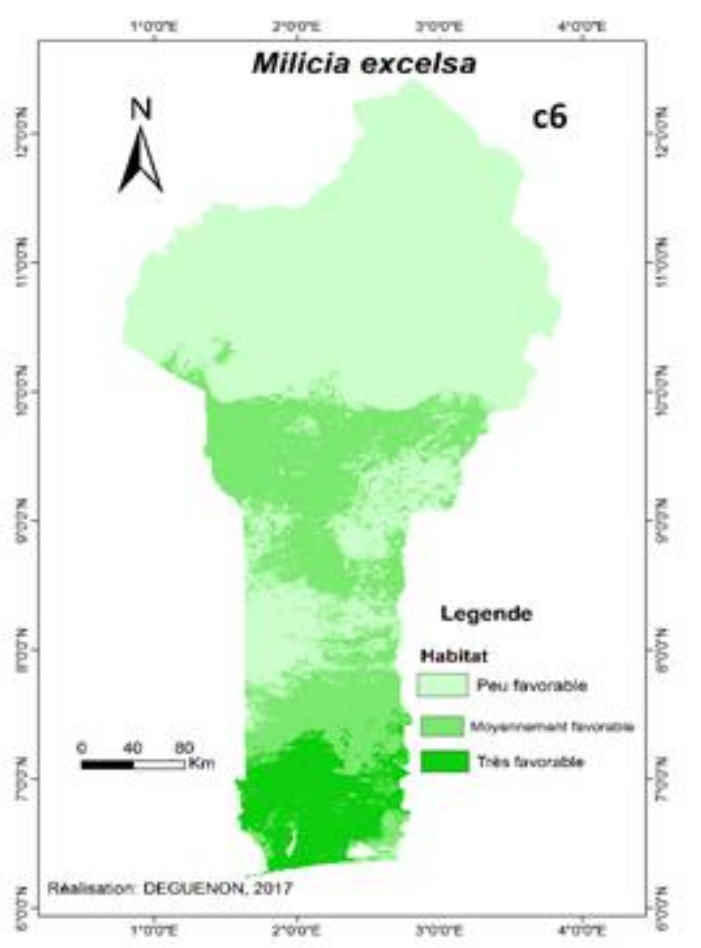


European Scientific Journal, ESJ

March 2021 edition Vol.17, No.10

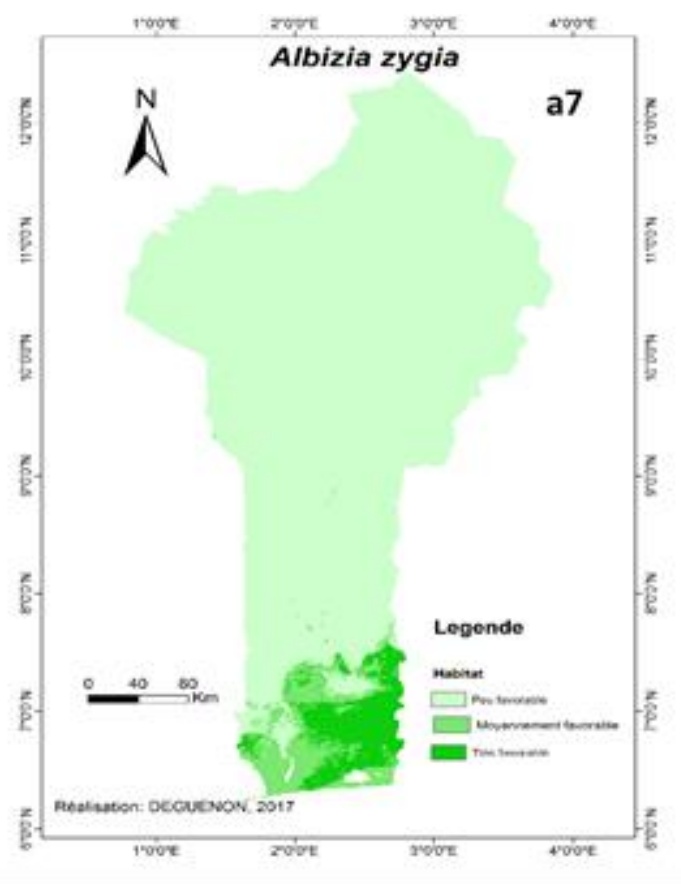

ISSN: 1857-7881 (Print) e - ISSN 1857-7431

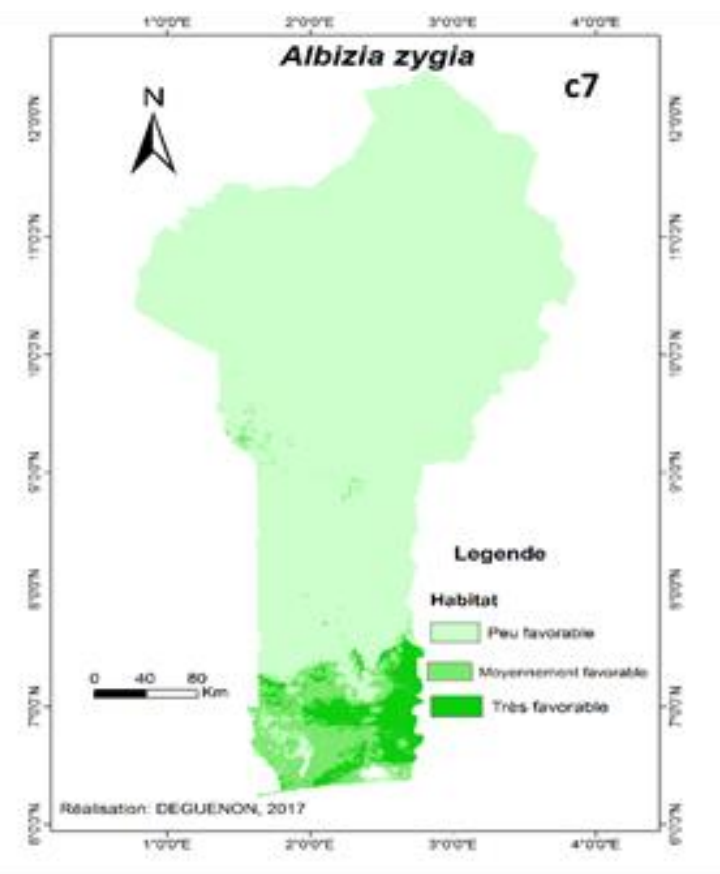


European Scientific Journal, ESJ

March 2021 edition Vol.17, No.10

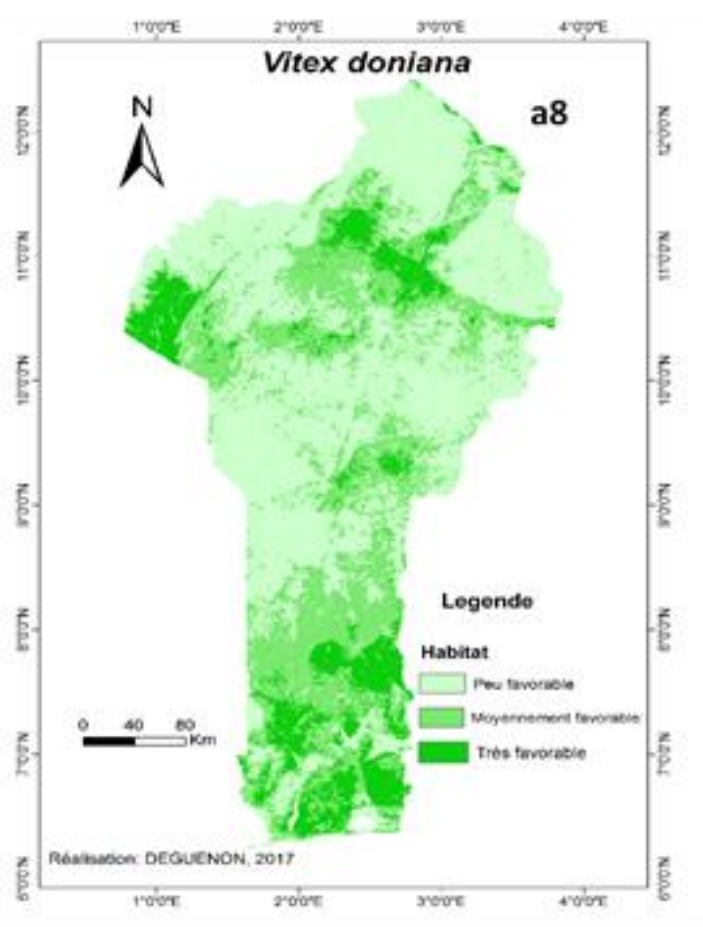

ISSN: 1857-7881 (Print) e - ISSN 1857-7431

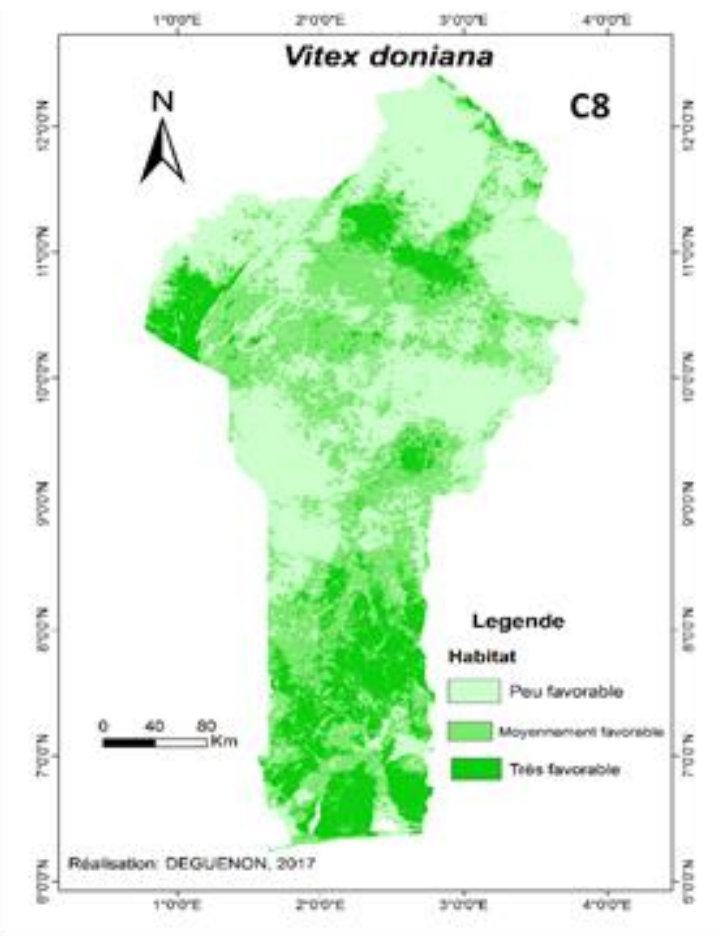


European Scientific Journal, ESJ

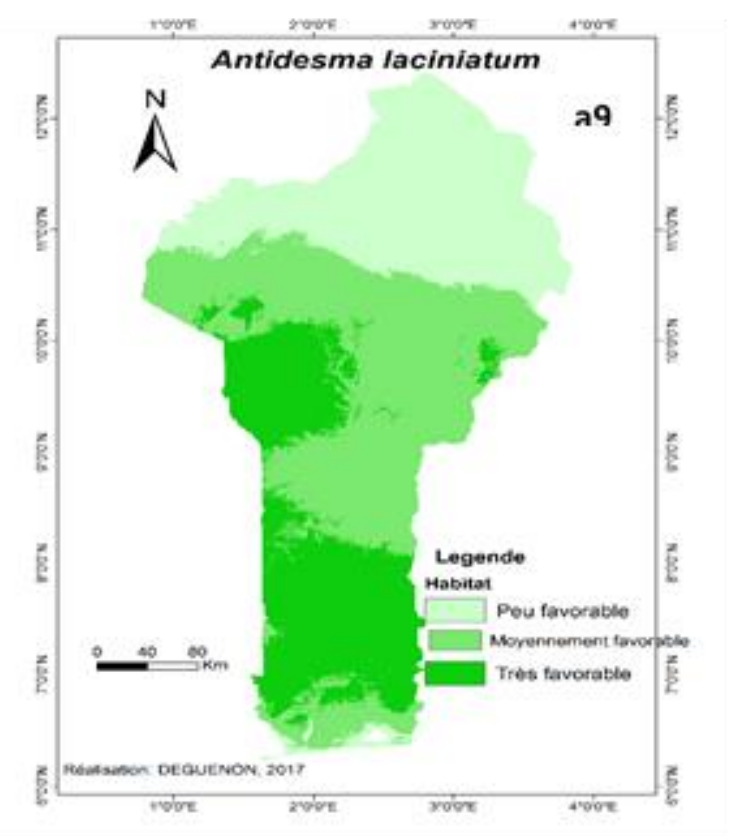

ISSN: 1857-7881 (Print) e - ISSN 1857-7431

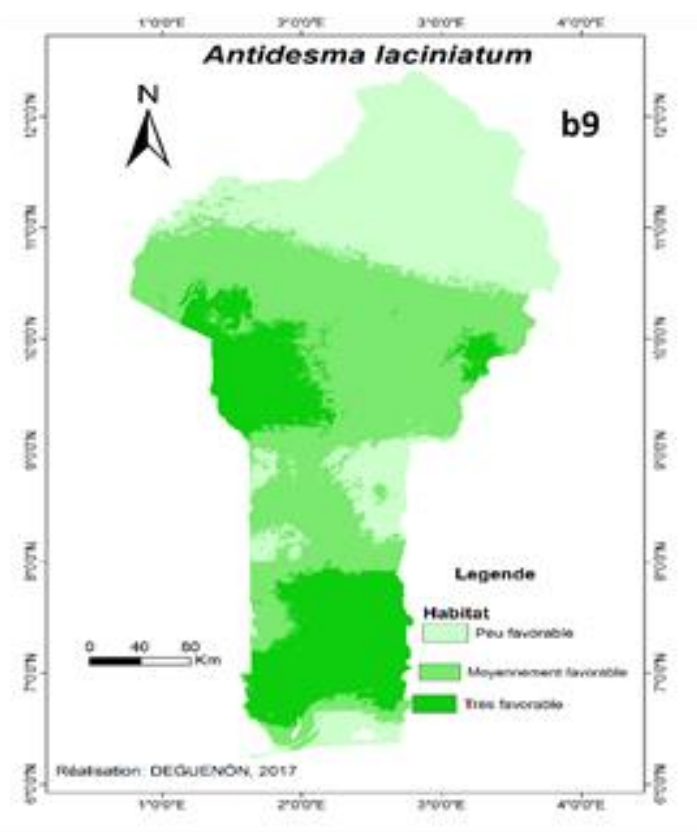

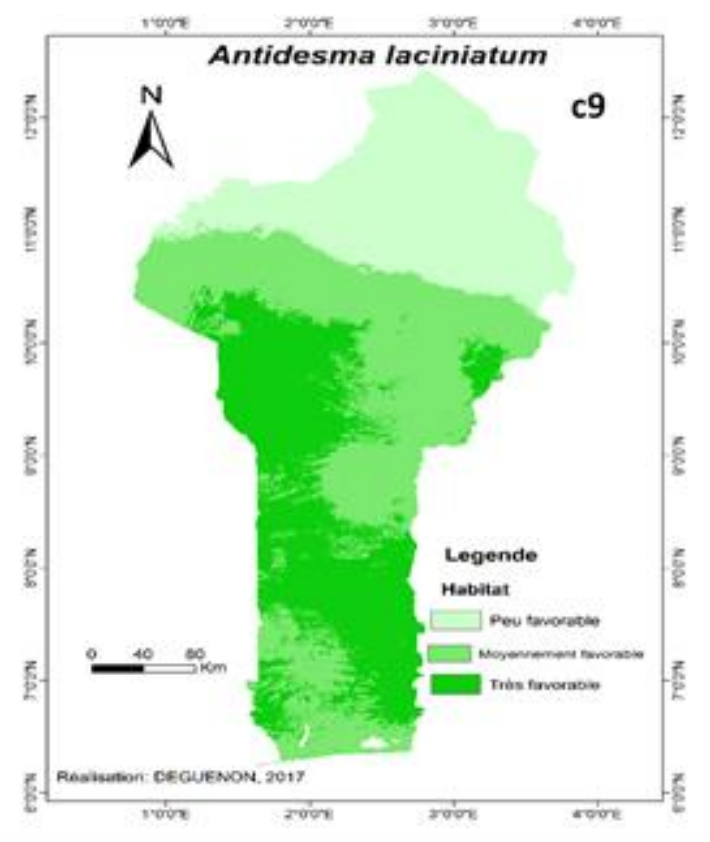


European Scientific Journal, ESJ

March 2021 edition Vol.17, No.10

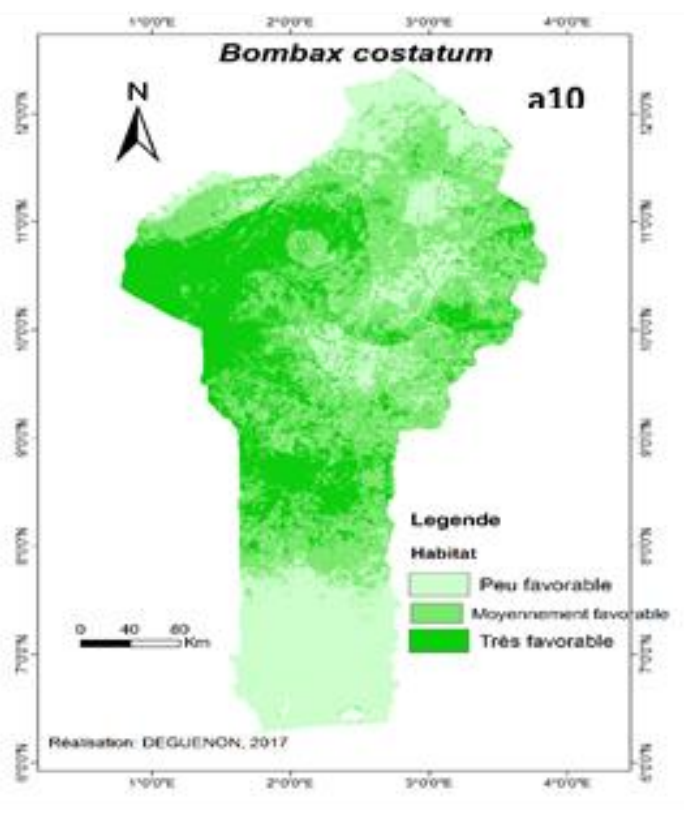

ISSN: 1857-7881 (Print) e - ISSN 1857-7431

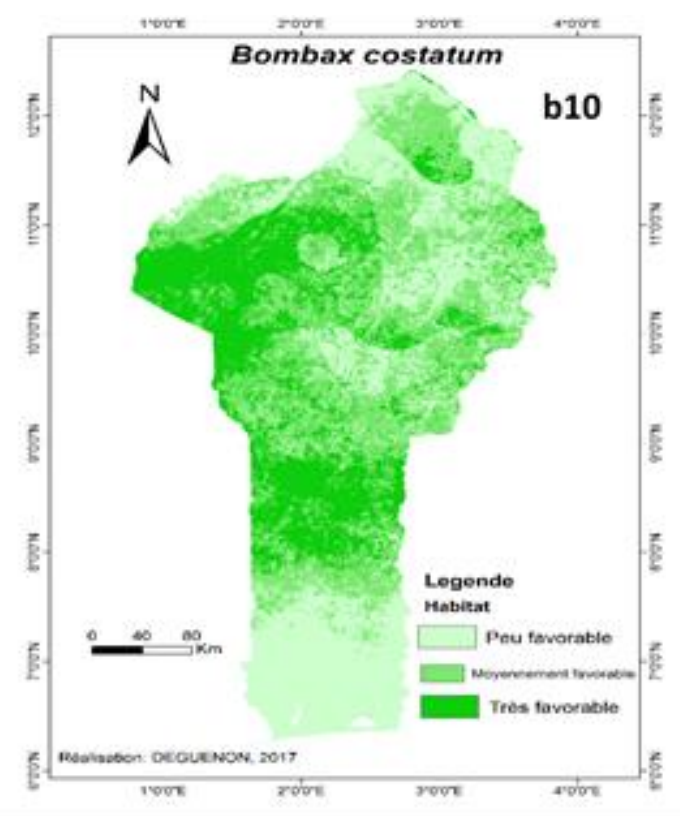

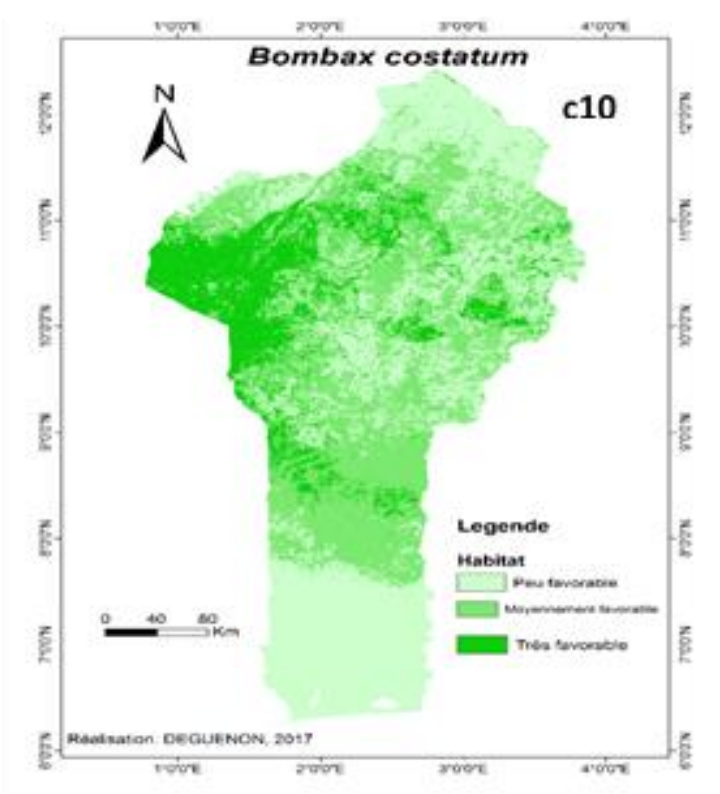


Table 4: Dynamics of areas favorable to the cultivation of ten priority species in classified forests under ONAB management

\begin{tabular}{|c|c|c|c|c|c|c|c|}
\hline \multirow{2}{*}{ Species } & \multirow[t]{2}{*}{ Culture } & \multicolumn{2}{|c|}{ Very favorable area } & \multicolumn{2}{|c|}{ Relatively favorable area } & \multicolumn{2}{|c|}{ Unfavorable area } \\
\hline & & Area $\left(\mathrm{Km}^{2}\right)$ & Trend (\%) & Area $\left(\mathrm{Km}^{2}\right)$ & Trend $(\%)$ & Area $\left(\mathrm{Km}^{2}\right)$ & Trend (\%) \\
\hline \multirow[t]{3}{*}{ K. senegalensis } & Present & 7790,164 & - & 27314,599 & - & 77519,238 & - \\
\hline & CNRM-CM5 & 9929,806 & $-27,464$ & 30909,969 & $-13,163$ & 71784,224 & 7,398 \\
\hline & HadGEM-ES & 8409,673 & $-7,952$ & 34605,718 & $-26,693$ & 69608,608 & 10,205 \\
\hline \multirow[t]{3}{*}{ A. africana } & Present & 17909,042 & - & 48910,364 & - & 45804,594 & - \\
\hline & CNRM-CM5 & 16454,677 & 8,121 & 48025,613 & 1,809 & 48143,709 & $-5,107$ \\
\hline & HadGEM-ES & 20204,166 & $-12,815$ & 48230,988 & 1,389 & 44188,846 & 3,527 \\
\hline \multirow{3}{*}{ K. grandifoliola } & Present & 2389,997 & - & 13675,684 & - & 96558,3194 & - \\
\hline & CNRM-CM5 & 1948,035 & 18,492 & 10446,984 & 23,609 & 100228,981 & $-3,801$ \\
\hline & HadGEM-ES & 2672,083 & $-11,803$ & 16187,653 & $-18,368$ & 93764,2639 & 2,894 \\
\hline \multirow[t]{3}{*}{ P. erinaceus } & Present & 2891,621 & - & 15189,574 & - & 94542,805 & - \\
\hline & CNRM-CM5 & 2597,163 & 10,183 & 12693,420 & 16,433 & 97333,417 & $-2,952$ \\
\hline & HadGEM-ES & 2958,358 & $-2,308$ & 24578,451 & $-61,811$ & 85087,191 & 10,001 \\
\hline \multirow[t]{3}{*}{ A. leiocarpa } & Present & 5244,454 & - & 25873,081 & - & 81506,464 & - \\
\hline & CNRM-CM5 & 3024,471 & 42,330 & 29898,506 & $-15,558$ & 79701,028 & 2,215 \\
\hline & HadGEM-ES & 2797,468 & 46,658 & 34433,035 & $-33,084$ & 75393,496 & 7,499 \\
\hline
\end{tabular}




\begin{tabular}{|c|c|c|c|c|c|c|c|}
\hline \multirow[t]{3}{*}{ M. excelsa } & Present & 9008,450 & - & 35217,968 & - & 68397,582 & - \\
\hline & CNRM-CM5 & 8998,887 & 0,106 & 35288,738 & $-0,201$ & 68336,375 & 0,089 \\
\hline & HadGEM-ES & 9498,825 & $-5,443$ & 31134,080 & 11,596 & 71991,095 & $-5,254$ \\
\hline \multirow[t]{3}{*}{ A. zygia } & Present & 5591,592 & - & 5970,558 & - & 101061,85 & - \\
\hline & CNRM-CM5 & 3368,451 & 39,759 & 7410,592 & $-24,119$ & 101844,956 & $-0,775$ \\
\hline & HadGEM-ES & 4861,468 & 13,057 & 7361,158 & $-23,291$ & 100401,374 & 0,653 \\
\hline \multirow[t]{3}{*}{$V$. doniana } & Present & 14205,137 & - & 37432,126 & - & 60986,737 & - \\
\hline & CNRM-CM5 & 13641,975 & 3,964 & 37316,845 & 0,308 & 61665,180 & $-1,112$ \\
\hline & HadGEM-ES & 19806,766 & $-39,434$ & 41392,169 & $-10,580$ & 51425,065 & 15,679 \\
\hline \multirow[t]{2}{*}{ Species } & Culture & \multicolumn{2}{|c|}{ Very favorable area } & \multicolumn{2}{|c|}{ Relatively favorable area } & \multicolumn{2}{|c|}{ Unfavorable area } \\
\hline & & Area $\left(\mathrm{Km}^{2}\right)$ & Trend $(\%)$ & Area $\left(\mathrm{Km}^{2}\right)$ & Trend (\%) & Area $\left(\mathrm{Km}^{2}\right)$ & Trend $(\%)$ \\
\hline \multirow[t]{3}{*}{ A. laciniatum } & Present & 31001,917 & - & 46185,033 & - & 35437,050 & - \\
\hline & CNRM-CM5 & 24969,994 & 19,457 & 47885,059 & $-3,681$ & 39768,947 & $-12,224$ \\
\hline & HadGEM-ES & 35434,598 & $-14,298$ & 43602,515 & 5,592 & 33586,887 & 5,221 \\
\hline \multirow[t]{3}{*}{ B. costatum } & Present & 30042,872 & - & 48393,144 & - & 34187,984 & - \\
\hline & CNRM-CM5 & 30029,613 & 0,044 & 46054,616 & 4,832 & 36539,771 & $-6,879$ \\
\hline & HadGEM-ES & 18152,927 & 39,576 & 49183,571 & $-1,633$ & 45287,502 & $-32,466$ \\
\hline
\end{tabular}




\section{Discussion}

\section{Modeling, Model Reliability, and Contribution of Variables}

Modeling of species distribution is widely used nowadays to determine favorable habitats at large scales and to produce comprehensive maps that are particularly used for identifying areas where conservation efforts are needed (Hounkpèvi et al., 2016 ). During this study, the CNRM-CM5 and HadGEMES models were used to predict the future distribution of 10 priority species. The results of this study revealed that the model presents good discrimination of the ecological niche for each of the priority species (AUC mean ratio >1). Thus, the current distribution areas predicted by the model for each species constitute areas of high probability where the species would be present or absent depending on the related ecological conditions. Overall, the distribution of these species depends on climatic and edaphic factors. Variables such as precipitation in the driest quarter, annual precipitation, annual thermal amplitude, and isothermality were found to be the most relevant for most species. This result confirms the fact that direct parameters such as temperature and precipitation are more effective when the modeling of the distribution of species concerns a large area, unlike indirect parameters such as altitude, topography, plant cover which are effective for small areas (Guisan and Zimmermann, 2000). Any significant change in the average states of the climate could therefore generate profound upheavals in the distribution of these species. Climate change is now recognized as one of the main threats to the survival of species and the integrity of ecosystems around the world (Fandohan et al., 2013). Similar results were obtained by Idohou et al. (2016) who showed that the distribution of wild palm depends on these same factors. Other studies have shown that the distributions of species such as Afzelia africana, Anogeissus leiocarpa, Khaya senegalensis (Adjahossou et al., 2016) and Vitex doniana (Hounkpèvi et al., 2016) are sensitive to environmental variations at several spatial scales.

The used prediction models show that the current distribution areas of the species will undergo profound changes in the future. For Khaya senegalensis, the two models used predicted an extension of moderately favorable and very favorable areas by conversion of unfavorable areas. For species such as Anogeissus leiocarpa and Albizia zygia, very favorable areas will experience a retraction in favor of moderately favorable areas. While Vitex doniana will experience a retraction of its very favorable range according to the CNRM-CM5 model, the HadGEM-ES model foresees rather a large extension of the very favorable ranges. Climate change could generate a spatial dynamic in the geographic distribution of habitats favorable to these species and thus make certain regions favorable today, very unfavorable in the future and vice versa (Hannah et al., 2002). For a good conservation action, it would be preferable to study for each of these species the tolerance limits of 
these two parameters (water and temperature) which significantly affect the distribution through the phytodistricts. Most species with a wide distribution (Vitex doniana, Afzelia africana, Antidesma laciniatum, Bombax costatum) are expected to remain fairly stable under the effect of future climate changes, even under the most drastic scenarios. According to Adjahossou et al. (2016), species such as Khaya senegalensis, Anogeissus leiocarpa and Afzelia africana being potential agroforestry species, used in agroforestry systems in the Guinean zone, where there are very few protected areas, could be considered in reforestation policies.

\section{Implications of the Study}

Overall, the distribution of these species depends on climatic and edaphic factors. The direct (driest quarter precipitation, annual precipitation) and indirect (soil) parameters were found to be more effective in predicting favorable priority areas in the conservation of the species studied. The SudanoGuinean $\left(7^{\circ} 30^{\prime}-11^{\circ} 5^{\prime} \mathrm{N}\right)$ and Guinean $\left(6^{\circ} 25^{\prime}-7^{\circ} 30^{\prime} \mathrm{N}\right)$ zones appear to be more concentrated in priority habitats, while the Sudanese zone $\left(10^{\circ} 00^{\prime}-12\right.$ ${ }^{\circ} 27^{\prime} \mathrm{N}$ ) is found to be concentrated in non-priority habitats. These areas seem likely to provide the ten species with suitable climatic conditions for their cultivation and conservation. Restoration policies combining in situ conservation strategies for the ten species should favor these priority unprotected areas because they are likely to provide the species with adequate climatic conditions. Also, the constitution of databases on the potential impact of climate change on forest species according to the different scenarios available could accelerate adaptive decision-making for their regeneration.

\section{References:}

1. Adjahossou, S. G. C., Nounagnon Gouwakinnou, G., Houehanou, D. T., Sode, A. I., Yaoitcha, A. S., Houinato, M. R. B., and Sinsin, B. (2016). Efficacité des aires protégées dans la conservation des habitats favorables prioritaires de ligneux de valeur au Bénin. Bois et Forêts des Tropiques 2.

2. Adomou, A. (2005). "Vegetation patterns and environmental gradients in Benin."

3. Adomou, A. C., Sinsin, B., and Van der Maesen, L. J. G. (2006). Notulae Florae Beninensis 12: Phytosociological and Chorological Approaches to Phytogeography: A Meso-Scale Study in Benin. Systematics and geography of plants, 155-178.

4. Assogbadjo, A. E., Kakaï, R. G., Chadare, F., Thomson, L., Kyndt, T., Sinsin, B., and Van Damme, P. (2008). Folk classification, perception, and preferences of baobab products in West Africa: consequences for species conservation and improvement. Economic Botany62, 74-84. 
5. Austin, M. P., and Van Niel, K. P. (2011). Improving species distribution models for climate change studies: variable selection and scale. Journal of Biogeography38, 1-8.

6. Barve, N., Barve, V., Jiménez-Valverde, A., Lira-Noriega, A., Maher, S. P., Peterson, A. T., Soberen, J., and Villalobos, F. (2011). The crucial role of the accessible area in ecological niche modeling and species distribution modeling. Ecological Modelling222, 1810-1819.

7. Baxter, E. J., Scott, L. M., Campbell, P. J., East, C., Fourouclas, N., Swanton, S., Vassiliou, G. S., Bench, A. J., Boyd, E. M., and Curtin, N. (2005). Acquired mutation of the tyrosine kinase JAK2 in human myeloproliferative disorders. The Lancet365, 1054-1061.

8. Boko, M., Niang, I., Nyong, A., Vogel, C., Githeko, A., Medany, M., Osman-Elasha, B., Tabo, R., and Yanda, P. (2007). Africa. Cambridge University Press.

9. Busby J.R., 1991. BioClim - a bioclimatic analysis and prediction system. In: Margules C.R. \& Austin M.P., eds. Nature conservation: cost effective biological surveys and data analysis. Canberra: CSIRO, 64-68.

10. Deryng, D., Sacks, W., Barford, C., and Ramankutty, N. (2011). Simulating the effects of climate and agricultural management practices on global crop yield. Global biogeochemical cycles 25 .

11. Djègo-Djossou, S. (2003). Détermination de l'aire de répartition de la population du colobe magistrat (Colobusvellerosus) et statut de conservation au Bénin. Mémoire de DESS/FSA-Université d'Abomey Calavi, Bénin. 97p.

12. Duveiller, E., Singh, R. P., and Nicol, J. M. (2007). The challenges of maintaining wheat productivity: pests, diseases, and potential epidemics. Euphytica157, 417-430.

13. Fandohan, B., Gouwakinnou, G. N., Fonton, N. 1. H., Sinsin, B., and Liu, J. (2013). Impact des changements climatiques sur la répartition geographique des aires favorables à la culture et à la conservation des fruitiers sous-utilisés: cas du tamarinier au Bénin. Biotechnologie, Agronomie, Société et Environnement 17, 450.

14. Fielding, A. H., and Bell, J. F. (1997). A review of methods for the assessment of prediction errors in conservation presence/absence models. Environmental conservation 24, 38-49.

15. Guisan, A., and Zimmermann, N. E. (2000). Predictive habitat distribution models in ecology. Ecological modelling 135, 147-186.

16. Hannah, L., Midgley, G. F., and Millar, D. (2002). Climate changeintegrated conservation strategies. Global Ecology and Biogeography11, 485-495. 
17. Heller N.E. \&Zavaleta E.S., 2009. Biodiversity management in the face of climate change: a review of 22 years of recommendations. Biol. Conserv., 142, 14-32.

18. Houehanou, T. D., Assogbadjo, A. E., Kakaï, R. G., Kyndt, T., Houinato, M., and Sinsin, B. (2013). How far a protected area contributes to conserve habitat species composition and population structure of endangered African tree species (Benin, West Africa). Ecological Complexity13, 60-68.

19. Hounkpèvi, A., Azihou, A. F., Kouassi, É. K., Porembski, S., and Kakaï, R. G. (2016). Climate-induced morphological variation of black plum (Vitex doniana Sw.) in Benin, West Africa. Genetic resources and crop evolution63, 1073-1084.

20. Idohou, R., Assogbadjo, A. E., Azihou, F., Kakaï, R. G., and Adomou, A. (2016). Influence of the landscape context on stand structure and spatial patterns of the doum palm (Hyphaene thebaica Mart.) in the Republic of Benin (West Africa). Agroforestry systems90, 591-605.

21. Jones, G., Steketee, R. W., Black, R. E., Bhutta, Z. A., Morris, S. S., and Group, B. C. S. S. (2003). How many child deaths can we prevent this year? The lancet362, 65-71.

22. Jovic, M., Sharma, M., Rahajeng, J., and Caplan, S. (2010). The early endosome: a busy sorting station for proteins at the crossroads. Histology and histopathology25, 99.

23. Lobo, J. M., Jiménez-Valverde, A., and Real, R. (2008). AUC: a misleading measure of the performance of predictive distribution models. Global ecology and Biogeography 17, 145-151.

24. Parry, M. L., Canziani, O. F., Palutikof, J. P., van der Linden, P. J., and Hanson, C. E. (2007). IPCC, 2007: climate change 2007: impacts, adaptation and vulnerability. Contribution of working group II to the fourth assessment report of the intergovernmental panel on climate change. Cambridge University Press, Cambridge.

25. Phillips, S. J., Anderson, R. P., and Schapire, R. E. (2006). Maximum entropy modeling of species geographic distributions. Ecological modelling 190, 231-259.

26. Sala, O. E., Chapin, F. S., Armesto, J. J., Berlow, E., Bloomfield, J., Dirzo, R., Huber-Sanwald, E., Huenneke, L. F., Jackson, R. B., and Kinzig, A. (2000). Global biodiversity scenarios for the year 2100. science 287, 1770-1774.

27. Saupe, E., Barve, V., Myers, C., Soberón, J., Barve, N., Hensz, C., Peterson, A., Owens, H., and Lira-Noriega, A. (2012). Variation in niche and distribution model performance: the need for a priori assessment of key causal factors. Ecological Modelling237, 11-22. 
28. Swets, J. A. (1988). Measuring the accuracy of diagnostic systems. Science 240, 1285-1293.

29. Vodouhê, F. G., Coulibaly, O., Greene, C., and Sinsin, B. (2009). Estimating the local value of non-timber forest products to pendjari biosphere reserve dwellers in Benin. Economic Botany63, 397.

30. Wisz, M. S., Hijmans, R., Li, J., Peterson, A. T., Graham, C., and Guisan, A. (2008). Effects of sample size on the performance of species distribution models. Diversity and Distributions 14, 763-773.

31. Zuur, A. F., Ieno, E. N., and Elphick, C. S. (2010). A protocol for data exploration to avoid common statistical problems. Methods in Ecology and Evolution 1, 3-14. 